\title{
Genome-wide identification of new reference genes for RT- qPCR normalization in CGMMV-infected Lagenaria siceraria
}

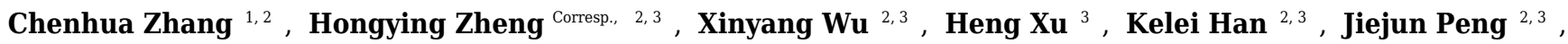 \\ Yuwen Lu ${ }^{2,3}$, Lin Lin ${ }^{2,3}$, Pei Xu ${ }^{2,4}$, Xiaohua Wu ${ }^{2,4}$, Guojing Li ${ }^{2,4}$, Jianping Chen ${ }^{1,2,3}$, Fei Yan ${ }^{\text {Corresp. 2, } 3}$ \\ ${ }^{1}$ College of Life Sciences, Fujian Agriculture and Forestry University, Fuzhou, China \\ 2 The State Key Laboratory Breeding Base for Sustainable Control of Pest and Disease, Zhejiang Academy of Agricultural Sciences, Hangzhou, China \\ 3 Key Laboratory of Biotechnology in Plant Protection of MOA of China and Zhejiang Province, Institute of Virology and Biotechnology, Zhejiang Academy \\ of Agricultural Sciences, Hangzhou, China \\ 4 Institute of Vegetable, Zhejiang Academy of Agricultural Sciences, Hangzhou, China \\ Corresponding Authors: Hongying Zheng, Fei Yan \\ Email address: zhenghongyinghz@163.com, fei.yan@mail.zaas.ac.cn
}

Lagenaria siceraria is an economically important cucurbitaceous crop, but suitable reference genes (RGs) to use when the plants are infected by cucumber green mottle mosaic virus (CGMMV) have not been determined. 16 candidate RGs of both leaf and fruit and 18 candidate RGs mostly from separate RNA-Seq datasets of bottle gourd leaf or fruit were screened and assessed by RT-qPCR. The expression stability of these genes was determined and ranked using geNorm, NormFinder, BestKeeper and RefFinder.

Comprehensive analysis resulted in the selection of $L S C Y P, L S H 3$, and $L S T B P$ as the optimal RGs for bottle gourd leaves, and $L S P 4 H, L S A D P$, and $L S T B P$ for fruits. $L S W D, L S G A P D H$, and LsH3 were optimal for use in both leaves and fruits under the infection of CGMMV. Isopentenyl transferase (IPT) and DNA-directed RNA polymerase (DdRP) were used to validate the applicability of the most stable identified RGs from bottle gourd in response to CGMMV. All the candidate RGs performed in RT-qPCR consistently with the data from the transcriptome database. The results demonstrated that $L s W D, L S G A P D H$ and $L s H 3$ were the most suitable internal RGs for the leaf, and $L s H 3, L s G A P D H, L s P 4 H$ and $L s C Y P$ for the fruit. 
1 Genome-wide identification of new reference genes for RT-qPCR

\section{normalization in CGMMV-infected Lagenaria siceraria}

Chenhua Zhangl, 2, \#, Hongying Zheng, 3, \#, Xinyang $W u^{2,3}$, Heng Xu ${ }^{3}$, Kelei Han ${ }^{2,3}$, Jiejun

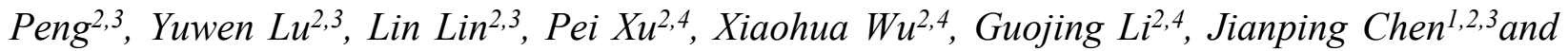
Fei $\mathrm{Yan}^{2,3 *}$

${ }^{1}$ College of Life Sciences, Fujian Agriculture and Forestry University, Fuzhou, China

2 The State Key Laboratory Breeding Base for Sustainable Control of Pest and Disease, Zhejiang Academy of Agricultural Sciences, Hangzhou, China

${ }^{3}$ Key Laboratory of Biotechnology in Plant Protection of MOA of China and Zhejiang Province, Institute of Virology and Biotechnology, Zhejiang Academy of Agricultural Sciences, Hangzhou, China

${ }^{4}$ Institute of Vegetable, Zhejiang Academy of Agricultural Sciences, Hangzhou, China

\# These authors contributed equally to this work.

*Authors for correspondence; Tel: +86-571-8640-4003; Fax: +86-571-8640-4258. E-Mail: zhenghongyinghz@163.com (H. Z.) and fei.yan@mail.zaas.ac.cn (F.Y.)

\section{ABSTRACT}

Lagenaria siceraria is an economically important cucurbitaceous crop, but suitable reference genes (RGs) to use when the plants are infected by cucumber green mottle mosaic virus (CGMMV) have not been determined. 16 candidate RGs of both leaf and fruit and 18 candidate RGs mostly from separate RNA-Seq datasets of bottle gourd leaf or fruit were screened and assessed by RT-qPCR. The expression stability of these genes was determined and ranked using geNorm, NormFinder, BestKeeper and RefFinder. Comprehensive analysis resulted in the selection of $L s C Y P, L s H 3$, and $L s T B P$ as the optimal RGs for bottle gourd leaves, and $L s P 4 H$, $L s A D P$, and $L s T B P$ for fruits. $L s W D, L s G A P D H$, and $L s H 3$ were optimal for use in both leaves and fruits under the infection of CGMMV. Isopentenyl transferase (IPT) and DNA-directed RNA polymerase $(D d R P)$ were used to validate the applicability of the most stable identified RGs from bottle gourd in response to CGMMV. All the candidate RGs performed in RT-qPCR consistently with the data from the transcriptome database. The results demonstrated that $L s W D$, $L s G A P D H$ and $L s H 3$ were the most suitable internal RGs for the leaf, and $L s H 3, L s G A P D H$, $L s P 4 H$ and $L s C Y P$ for the fruit.

\section{INTRODUCTION}

Lagenaria siceraria (Molina) Standl. is a specie belongs to Cucurbitaceae family,which was 
cultivated widely in tropical and temperate regions of the world, it is commonly known as bottle gourd that has good edible, medicinal and horticultural value (Wang et al., 2018; Decker-Walters et al., 2004). It could be routinely used as one rootstock source for watermelon and other cucurbit crops in both Japan and Korea in order to reduce the incidence of soil-borne diseases and promote the vigor of the root system of the crops in low temperature conditions (Yetisir et al., 2013; Cho et al., 2017; Spalholz et al., 2017). Medicinally, L. siceraria extract has radioprotective potential in radiation-induced gastrointestinal injury (Sharma et al., 2016), and its latex sap exhibits potent lectin activity to mitigate neoplastic malignancy by targeting neovasculature and cell death (Vigneshwaran et al., 2016). Recently, a dedicated database named GourdBase was developed, which promoted the study of biological traits and molecular breeding in the bottle gourd (Wang et al., 2018). Zhejiang province has a long history of cultivating bottle gourd as an important economic crop. In 2011, the leaves of a bottle gourd plant which were brittle and had severe mosaic mottling were shown to be infected with cucumber green mottle mosaic virus (CGMMV) using reverse transcription-polymerase chain reaction (RT-PCR) and ELISA (Zheng et al., 2015). Since CGMMV could pose a great threaten to bottle gourd production, it attracted our attention.

CGMMV (genus Tobamovirus, family Virgaviridae) causes serious diseases in cucurbit crops. The virus is easily transmitted on the outside of seeds, pollen, and other propagation materials. It produces severe mosaic symptoms on the leaves of infected plants and causes fruit deformation, resulting in reduced yield and low market value (Ugaki et al., 1991; Sano et al., 1997; Tan et al., 2000; Zheng et al., 2015; Ali et al., 2012). It has a worldwide distribution, and has been reported from many countries, including Israel, China, Greece, USA, Saudi Arabia and Russia (Ali et al., 2012; Zheng et al., 2015; Slavokhotova et al., 2007; Antignus et al., 1990; Varveri et al., 2002; Ali et al., 2004; Amer, 2015).

In view of the significant economic losses to cucurbit crops caused by CGMMV, most research has focused on its detection and control. The interaction between CGMMV and its hosts has gained increasing attention recently, but knowledge about it is still limited. Several studies have focused on identifying novel and conserved microRNAs in response to CGMMV infection or virus-derived siRNAs in a CGMMV infected host and exploring the pathogenic mechanisms from the perspective of protein expression levels in its hosts (Liu et al., 2015; Li et al., 2016; Sun et al., 2017). Internal changes in the host involve the host-virus interaction system, which is often mediated at the transcriptional level, thereby altering gene expression and possibly indirectly affecting plant performance. Quantitative RT-PCR (RT-qPCR) has become the most common method for quantifying and comparing gene expression levels during virus infection because of its rapidity, sensitivity, and specificity (Radonić et al., 2014; Huggett et al., 2005; Ceelen et al., 2014). Reference genes (RGs) are used to minimize experimental errors and normalize the experimental data but these are not universal; different RGs are needed under different experimental conditions. In cucurbits, only a few RGs with different traits have been established, and there are no reports of RGs suitable for use with CGMMV-infected bottle gourd.

Several reference genes have been utilized for reliable RT-qPCR in cucurbit crops, including actin $(A C T)$, elongation factor 1 alpha subunit $(E F 1 \alpha)$, glyceraldehyde-3-phosphate 
$81(G A P D H)$, serine/threonine-protein phosphatase PP2A catalytic subunit (PP2A), Ran-GTPase 82 (RAN), 40S ribosomal protein S15-4 (RPS15), tubulin alpha (TUA), peptidyl-prolyl cis-trans 83 isomerase $(C Y P), 60 \mathrm{~S}$ ribosomal protein L23 (RPL23), ADP-ribosylation factor $(A D P)$, ubiquitin-60S ribosomal protein L40 (UBA) and transcription initiation factor TFIID TATA-boxbinding protein (TBP) (Kong et al., 2016; Kong et al., 2014; Wan et al., 2010; Wang et al., 2014; Warzybok et al., 2013; Sestili et al., 2014; Wu et al., 2016; Kong et al., 2014; Kong et al., 2015). In Nicotiana benthamiana, PP2A, F-Box and L23 are known to be the most stable RGs for exploring plant-virus interactions (Liu et al., 2012).

In this study, traditional reference genes were screened as candidate RGs and new, previously unreported, RGs were also sought. Systematic transcriptome analyses, including RNA-Seq and DNA microarray, have been widely used in the study of host-virus interaction recently. Because transcriptome data provide a valuable resource that can be used to determine appropriate RGs (Kudo et al., 2016; Guo et al., 2016; Marcolinogomes et al., 2015; Zhang et al., 2014; Liu et al., 2018), we screened potential internal RGs from the transcriptome database of bottle gourd infected by CGMMV. We set the corresponding screening parameters to select the candidate genes from the bottle gourd transcriptome database. 11 candidate RGs from leaves and 22 from fruits were selected, including a histon $\mathrm{H} 3$ gene $(L s H 3)$ and a tryptophan and aspartic acid (WD)repeat protein $(L S W D)$, which matched the screening parameters for both leaves and fruits.

The stability and suitability of all selected candidate RGs expression was estimated using several algorithms: geNorm, NormFinder, BestKeeper and RefFinder. These algorithms together provide an approach to identify the most stably transcribed new genes (i.e. in addition to the traditional reference genes). Because there is little information on RGs that can be used to normalize gene expression data in CGMMV-infected bottle gourd, we evaluated the selected candidate genes by RT-qPCR, focusing on novel reference gene selection and analysis in CGMMV-infected leaves and fruits. Moreover, parallel analyses on the expression profiles of an Isopentenyl transferase (IPT) gene and a DNA-directed RNA polymerase $(D d R P)$ gene normalized by the identified RGs were performed to demonstrate the reliability of these identified RGs.

\section{MATERIALS \& METHODS}

\section{Plant Preparation, Virus Inoculation}

The cultivation and management of bottle gourd (L. siceraria, accession "Hangzhou Gourd") were performed as follow: after soaking and germination, the seeds were first transplanted into $10 \mathrm{~cm}$ nutrient preparations with soil rich in organic matter, and when the seedlings grew to two and a half leaf stage, transplanted them into $20 \mathrm{~L} \mathrm{PVC} \mathrm{drums} \mathrm{(1} \mathrm{per} \mathrm{barrel).} \mathrm{The} \mathrm{mixed} \mathrm{substrate}$ used was peat: vermiculite: perlite: organic fertilizer $=4: 4: 1: 1$, The $\mathrm{pH}$ of the culture substrate was about 7.0 and the water content was maintained at about $70 \%$ relative humidity. Put a "flower-free" nutrient solution once a week (N:P:K=20:20:20) (Shanghai Yongtong Chemical Co., Ltd.). The greenhouse conditions were daily temperature $25-28{ }^{\circ} \mathrm{C}$, night temperature $18-20$ ${ }^{\circ} \mathrm{C}$; photoperiod $14 \mathrm{~h} / \mathrm{d}$ (light intensity is greater than $87.5 \mu \mathrm{mol} \cdot \mathrm{m}^{-2} \cdot \mathrm{s}^{-1}$ ). Scaffolding, topping, 
122 pruning and pollination were carried out according to routine management. The fruits were

123

124

125

126

127

128

129

130

131

132

133

134

135

136

137

138

139

140

141

142

143

144

145 harvested 10 days after pollination.

CGMMV inoculum (CGMMV-ZJ) was sap from L. siceraria plants with typical symptoms that had been infected with a CGMMV infectious clone $14 \mathrm{~d}$ earlier (Zheng et al., 2015). At least six plants were inoculated with CGMMV-infected sap at the two and a half leaf stage on the two expanding leaves. Approximately $1 \mathrm{~g}$ of plant tissue was homogenized in 20 volumes of inoculation buffer $(0.1 \mathrm{M}$ phosphate buffer, $\mathrm{pH} 7.5,0.2 \%$ sodium sulfite and $0.01 \mathrm{M} 2$ mercaptoethanol), while the mock plants were only inoculated with buffer.

\section{RNA sequencing}

According to the protocol of TruSeq Small RNA Sample Prep Kits (Illumina, USA), the total RNA of about $5 \mu \mathrm{g}$ was extracted for the preparation of small RNA library. Sequencing of the RNA-Seq libraries was carried out on an Illumina Hiseq2500 at LC-BIO (Hangzhou, China) following the manufacturer's protocol.

\section{RNA and First Strand cDNA Preparation}

Three replicate samples of flesh tissue of the ripe fruits and newly expanding leaves from both inoculated and control plants were collected for RNA extraction. Total RNA was extracted from each sample using TRIzol reagent (Invitrogen, Carlsbad, CA, USA) according to the manufacturer's instructions. The RNA quantity and quality from each sample was evaluated by denaturing agarose gel electrophoresis and microfluidic capillary electrophoresis with the Agilent 2100 bioanalyzer (Agilent technologies, USA). Only RNA samples with a complete band and A260/A280 ratio in the range 1.8-2.0 were used for the next step. All RNA samples were stored at $-70{ }^{\circ} \mathrm{C}$. For virus detection, the first strand cDNA was synthesized using ReverTra Ace $-\alpha-{ }^{\circledR}$ kit (TOYOBO, Japan) following the product's protocol. The infection of CGMMV in the tissues was confirmed by CGMMV specific primers, and the primers of ZYMV and WMV were also used to monitor the presence of these two common viruses occurred in cucurbit crops (Heeju et al., 2015). For RT-qPCR, first strand cDNA was synthesized from $1 \mu \mathrm{g}$ total RNA using PrimeScript ${ }^{\mathrm{TM}}$ RT reagent Kit with gDNA Eraser (Perfect Real Time) kit (TaKaRa, Dalian, China) according to the manufacturer's instructions. The negative controls without PrimeScript RT Enzyme Mix I were analyzed in parallel to detect the presence of genomic DNA contamination in the RNA samples.

\section{Selection of Candidate RGs}

Partial candidate RGs in leaves and fruits were selected from publicly available references, but most were from our RNA sequencing data. To obtain RGs that are stably and moderately or highly expressed in CGMMV-infected leaves, we kept the Reads Per Kilobases per Million reads (RPKM), ratio of the maximum to the minimum RPKM (RPKMmax/min), and coefficient of variation $(\mathrm{CV})$ to $>40,<2.0$, and $<0.3$ at $\mathrm{p}<0.05$, respectively. In fruit, the RPKM, $\mathrm{RPKMmax} / \mathrm{min}$, and CV were maintained at $>40,<2.0$, and $<0.2$ at $\mathrm{p}<0.05$, respectively. All selected internal RGs have only one transcript and were ranked from small to large according to 
their RPKMmax/min values.

To select better RGs for both leaves and fruits, the RPKM and RPKMmax/min were kept at $>$ 40 and $<2.0$ for the RGs commonly used in cucurbit plants in keeping with the RNA-seq data. The RGs for leaves and fruits were screened and analyzed simultaneously with 14 common RGs of cucurbit crops in previous studies. A total of 16 RGs from bottle gourd leaves and fruits were screened and analyzed.

\section{Primer Design and Verification of Selected Gene Amplicons}

The fourteen common RGs were amplified according to the references or based on primers designed by Primer-BLAST of the RNA sequence data of leaves and fruits (Table 1). Specific primers for the candidate RGs from our RNA-sequencing data were designed using Primer 3 (http://primer3.ut.ee) (Table 2). All PCR amplicon lengths were between 80-200 bp. All primers were synthesized by a commercial supplier (Biosune, Hangzhou, China).

To check the specificity of all primers, the cDNA of each sample was amplified by PCR, and the amplified products were separated by electrophoresis on 3\% agarose gel and purified using a QIAquick Gel Extraction Kit (Qiagen, Hilden, Germany) according to the manufacturer's instructions, and cloned into pEASY-Blunt zero (Transgen, Beijing, China) followed by sequencing.

The quantification cycle $(\mathrm{Cq})$ values obtained by qRT-PCR on a standard curve generated from a fourfold dilution series of one sample at six dilution points for three technical replicates were used to draw the standard curve to get R2 and slope values. The PCR amplification efficiency of each primer was calculated using the equation: $E($ Efficiency $) \%=\left(10^{\left[-1 / \text { slope }_{-}-1\right)}\right.$ $\times 100 \%$.

\section{Quantitative Real-Time PCR}

qRT-PCR was carried out in 384-well plates using the QuantStudio 6 Flex real-time PCR detection system (ABI, USA). Each reaction mixture consisted of $5 \mu \mathrm{L}$ SYBR Green Realtime PCR Master Mix (TaKaRa, Dalian, China), $0.5 \mu \mathrm{L}$ cDNA diluted fivefold, $0.5 \mu \mathrm{L}(10 \mathrm{mM})$ each of forward and reverse primers, and $3.5 \mu \mathrm{L}$ RNA-free $\mathrm{H}_{2} \mathrm{O}$, equating to a final volume of $10 \mu \mathrm{L}$ in each well. The qPCR reaction was as follows: initial denaturation at $95{ }^{\circ} \mathrm{C}$ for 5 min and 40 cycles of amplification $\left(95{ }^{\circ} \mathrm{C} 15 \mathrm{~s}, 58{ }^{\circ} \mathrm{C} 20 \mathrm{~s}\right.$ and $\left.72{ }^{\circ} \mathrm{C} 20 \mathrm{~s}\right)$. Subsequently, fluorescence acquisition was performed after each cycle. A melting curve was generated after 40 cycles of amplification by heating at $65-95{ }^{\circ} \mathrm{C}$. Cq values and baseline were set automatically by the QuantStudio Real-Time PCR Software v1.2 (ABI, USA) using default parameters.

\section{Gene expression stability analysis}

The programs geNorm (Vandesompele et al., 2002), NormFinder (Andersen et al., 2004), BestKeeper (Pfaffl et al., 2004) RefFinder (http://150.216.56.64/referencegene.php?type=reference) were used to analyze the stability of the candidate RGs under CGMMV infection conditions. All software packages were used according to the manufacturer's instructions. 
204

205

206

207

208

209

210

211

212

213

214

215

216

217

218

219

220

221

222

223

224

225

226

227

228

229

230

231

232

233

234

235

236

237

238

239

240

241

242

243

244

\section{Validation of the selected RGs}

LsIPT and LsDdRP genes in CGMMV-infected bottle gourd leaf and fruit tissue were selected to detect the effectiveness of these identified RGs. Primers for the two genes were designed as described above and listed in Table 1 . The best RGs identified by the algorithms above were used for normalization.

\section{RESULTS}

Transcriptome analysis of Lagenaria siceraria under CGMMV infection based on RNA-seq Bottle gourd leaves and fruits infected by CGMMV were collected from three replicate virusinoculated plants, and the presence of CGMMV in each sample was further confirmed by RTPCR and western blot, and the contamination of ZYMV and WMV was excluded by RTPCR(Fig. S1). The control leaves and fruits samples were in parallel collected from three mock bottle gourds. The analysis of bottle gourd transcripts before and after CGMMV infection showed 639 and 3930 non-differentially expressed genes $(\mid \log 2$ fold_change $\mid<1, \mathrm{P} \leqslant 0.05)$ in the leaves and fruits of bottle gourd, respectively (Tables S1 and S2). And these nondifferentially expressed genes were used as the source of candidate RGs from the RNA-Seq dataset.

\section{Selection of candidate RGs}

In the present study, 11 and 86 candidate RGs respectively from bottle gourd leaves and fruits were screened from our RNA-Seq dataset by setting up a series of conditions (Tables S3 and S4). Only 2 genes, $L s H 3$ and $L s W D$ (Table S5), met the criteria to be candidate RGs for both leaves and fruits. The primers were designed based on the gene sequences in the database. To select candidate RGs that could be used in both bottle gourd leaves and fruits, these 2 novel genes with other 14 traditional candidate RGs were used to compare their expression stability. To select candidate RGs that could be used in bottle gourd leaves or fruits, separately, the commonly used reference gene sequences were then compared with the bottle gourd transcriptome data (Table S6). All the 11 candidate RGs of bottle gourd leaves screened from our RNA-Seq data, and 7

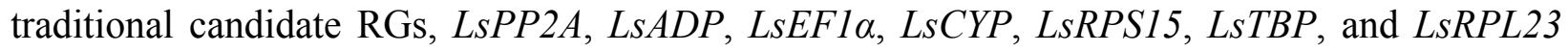
screened from transcriptome comparison data were selected as candidate RGs of bottle gourd leaves. Of the 86 genes screened from the bottle gourd fruit transcriptome data, the first 11 (based on the ratio of RPKMmax/min) were selected for further analysis in addition to $L s H 3$ and $L s W D$, and 5 traditional candidate RGs, LsPP2A,LsADP, LsTBP, LsTUA, and LsGAPDH screened from transcriptome comparison data were selected as candidate RGs of bottle gourd fruits. Therefore, a total of 16 common RGs of both bottle gourd leaves and fruits (Table 1) and 18 RGs of bottle gourd leaves and fruits separately were screened and analyzed (Tables 1 and 2).

\section{Evaluation of target specificity and amplification efficiency in RT-qPCR reactions}

Preliminary evaluation of candidate reference gene primers was performed by evaluating primer 
245

246

specificity and efficiency. The single peak in melting curve analyses following RT-qPCR confirmed the specific amplification of each gene (Fig. S2). Each amplicon was detected by agarose gel electrophoresis, only a single fragment of the expected size (80-200 bp) was observed (Fig. S3). Further sequencing results showed all genes sequences were exactly 100\% identical to those of the corresponding genes in bottle gourd transcriptome databases. Amplification efficiencies of bottle gourd leaves ranged from $90.1 \%$ to $110.1 \%$, whereas those of the fruits ranged from $89.9 \%$ to $116.2 \%$ (Tables 1 and 2 ). Furthermore, the standard curves showed good linear relationships $(>0.981)$ between the Cq values and the log-transformed copy numbers of all candidated RGs (Tables 1 and 2). There was no band detected in the negative controls, indicating that the genomic DNA contamination does not exist (Fig. S3).

\section{Expression intensity of candidate RGs}

In order to fully understand the relative expression intensity of all candidate RGs in bottle gourd, three biological and three technical replicates $(n=9$ for each gene) were used to determine the $\mathrm{Cq}$ values for all RGs. From the graph for bottle gourd leaves, the mean $\mathrm{Cq}$ values of these candidate genes we selected ranged from 16.51 ( $L s C Y P$ ) to 25.63 (LsTBP) (Fig. 1A), which represented the highest and lowest accumulation levels, respectively. The minimal variation in gene expression was $L s U B C(<0.81$ cycles $)$ in bottle gourd leaves. The lowest and highest median $\mathrm{Cq}$ value of the mRNA accumulation levels in the fruits of bottle gourd was 20.94 (LsH3) and $28.88(L s T B P)$, respectively (Fig. 1B). LsPLA expression exhibited the least amount of variation ( $<1.14$ cycles) in bottle gourd fruits. The Cq value 15.18 of $L s C Y P$ in leaves was the lowest and 28.04 of $L s P P 2 A$ in fruits was the highest (Fig. 1C). The minimal variation in gene expression observed in both leaves and fruits were 2.95 cycles $(L s A C T), 3.06$ cycles ( $L S A D P)$ and 3.78 cycles $(L s W D)$. However, only the comparison of raw $\mathrm{Cq}$ values is not sufficient to evaluate the expression stability of candidate RGs, a further intensive statistical analysis was required for more accurate assessment.

\section{Comparison of the expression stability of the universal traditional candidate RGs and novel candidate RGs in both bottle gourd leaves and fruits}

To select universal candidate RGs expressed stably both in bottle gourd leaves and fruits infected by CGMMV, we screened from our RNA-Seq dataset by setting up a series of conditions $(\mathrm{RPKMmax} / \min <2$, and $\mathrm{CV}<0.3, \mathrm{p}<0.05$, RPKM $\min >40)$. Only 2 genes, LsH3 and LsWD, met the criteria to be candidate RGs and we then compared the expression stability of these two novel genes with 14 other commonly-used cucurbit RGs. The expression profiles (Fig. 2A) and the variations of the 16 genes (Fig. 2B; Tables S5 and S6) in bottle gourd suggested that $L s W D$, $L s H 3$ and $L s T B P$ and $L s G A P D H$ were expressed more stably $(\mathrm{CV}<0.3)$, and the variation in respective expression levels was the lowest among all the genes during CGMMV infection, indicating that these genes, especially the two novel genes $L s W D$ and $L s H 3$, may be more suitable for normalization than other traditional candidate RGs. In addition, $L s W D, L s H 3$ and $L s G A P D H$ each had only 1 transcript, which could facilitate primer design and ensure the accuracy and reliability of the RT-qPCR compared to other genes. 
The stability of these 16 potential RGs was further evaluated with two statistical methods. By geNorm analysis, the average gene expression stability $(\mathrm{M})$ of all of the universal candidate RGs were compared, among them, $L s H 3$ and $L s G A P D H$ showed the lowest $\mathrm{M}$ value $(\mathrm{M}=0.284)$ in both leaves and fruits, followed by $\operatorname{LsWD}(\mathrm{M}=0.340)$ (Fig. 3A), indicating that these genes displayed the most stable profiles. Pairwise variation $V_{n / n+1}$ was less than 0.15 in all leaf and fruit samples (Fig. 3B), indicating that adding other RGs was not necessary, and demonstrating that at least two reference genes were required for more reliable normalization, the top two gene were $L s H 3$ and $L s G A P D H$. The raw $\mathrm{Cq}$ values were also transformed into Q values for NormFinder analysis. The lowest stability value of NormFinder analysis indicates the most stably expressed gene. By NormFinder analysis, the best three universal RGs in both leaf and fruit were LsTBP, $L s W D$ and $L s H 3$ (Fig. 4A). So, both geNorm and NormFinder analysis suggested that the two novel candidate RGs $L s W D$ and $L s H 3$ were suitable to evaluate the gene expression stability of bottle gourd leaves and fruits infected by CGMMV.

\section{Expression stability of candidate RGs in CGMMV infected leaves and fruits of bottle gourd separately from transcriptome analysis}

To further select more suitable candidate RGs expressed stably in bottle gourd leaves or fruits infected by CGMMV separately, 18 RGs of bottle gourd leaves or fruits separately obtained from the RNA-Seq dataset were compared using different algorithms. By geNorm analysis, the average gene expression stability of the 18 candidate RGs of bottle gourd leaves and fruits screened from the RNA-Seq were all less than 1.5, respectively (Figs. 3C and 3E; Table 2). For all the tested leaf samples, $L s T B P$ and $L s C Y P$ showed the lowest $M$ value $(M=0.213$ ) (Fig. $3 C$ ) of all the candidate RGs while in fruit samples, $L s P 4 H$ and $L s V A M P$ had the lowest $\mathrm{M}$ value $(\mathrm{M}=0.212)$ (Fig. 3E). The pairwise variation $\mathrm{V}_{\mathrm{n} / \mathrm{n}+1}$ of each sample was also less than 0.15 (Figs. $3 \mathrm{D}$ and $3 \mathrm{~F}$ ), and the top two reference genes those had the lowest $\mathrm{M}$ value were needed for more reliable normalization at least. Similarly, by NormFinder analysis, the best three genes screened from the RNA-Seq dataset were $L s C Y P, L s H 3$ and $L s P P 2 A$ in leaves (Fig. 4B), and $L s T B P$, $L s P 4 H$ and $L s X R N 1$ in fruits (Fig. 4C).

For further clarification, the expression stability of these candidate RGs was examined by two more algorithms. BestKeeper software can only compare the expression levels of up to 10 internal control genes in 100 samples, so only the top ten genes identified by geNorm and NormFinder were selected for subsequent assessment. Of these, the top three candidate internal RGs were $L s C Y P(\mathrm{r}=0.995$, p-value $=0.001), L s H 3(\mathrm{r}=0.984$, $\mathrm{p}$-value $=0.001)$ and $L s T B P(\mathrm{r}=$ 0.964 , $\mathrm{p}$-value $=0.002)$ in leaf samples, and $L s P 4 H(\mathrm{r}=0.978, \mathrm{p}$-value $=0.001)$, s $V A M P(\mathrm{r}=$ $0.975, \mathrm{p}$-value $=0.001)$ and $\operatorname{LsTBP}(\mathrm{r}=0.959, \mathrm{p}$-value $=0.002)$ in fruit samples $($ Table $\mathrm{S} 7)$. The results of BestKeeper were therefore broadly consistent with geNorm and NormFinder. We also compared and ranked the tested candidate RGs based on a web-based comprehensive analysis tool, RefFinder, which suggested that the top three candidate RGs screened from the RNA-Seq dataset in bottle gourd leaves were $L s C Y P, L s H 3$ and $L s T B P$, while those in bottle gourd fruits were $L s P 4 H, L s A D P$, and $L s T B P$ (Table S7). These should therefore be the best RGs to use in RT-qPCR. 


\section{Validation of the candidate RGs}

329

330

331

332

333

334

335

336

337

338

339

340

According to the transcriptional data, expression of the IPT and DdRP genes of L. siceraria changed significantly in response to CGMMV. LSIPT increased 1.78 fold in leaves and decreased 1.2 fold in fruits compared with their mock-inoculated tissues, while LsDdRP increased 1.4 fold in leaves and increased 1.63 fold in fruits (Table S8). These genes were therefore chosen to evaluate the reliability of the top candidate RGs as indicated by the previous analysis. The top rank RGs $L s H 3, L s G A P D H, L s W D, L s C Y P, L s T B P$ and $L s P 4 H$ selected by geNorm and RefFinder were used as candidate RGs. Among them, LsTBP, LsWD, LsH3, $L s G A P D H$ and $L s C Y P$ were selected to use as RGs in leaves, and all these genes together with $L s P 4 H$ for fruit.

$L S I P T$ increased 2.75 fold when $L s W D$ was used as the reference gene in leaves, with 2.95, $3.82,3.93$ and 4.43 fold increases using $L s G A P D H, L s H 3, L s C Y P$ and $L s T B P$ respectively. The values of $L S I P T$ normalized fold expression in fruits were 0.54 (LsTBP), 0.52 (LsWD), 0.60 ( $L s H 3$ ), 0.57 (LsGAPDH), 0.59 ( $L s C Y P$ ) and $0.56(L s P 4 H)$ (Fig. 5). LsDdRP increased 1.78, 1.95, 2.51, 2.57 and 2.88 fold in leaves when $L s W D, L s G A P D H, L s H 3, L s C Y P$ and $L s T B P$ were the internal RGs respectively, while the corresponding values in fruits were $1.42(L s W D), 1.53$ (LsTBP), 1.60 (LsH3), 1.62 (LsGAPDH), 1.80 (LsP4H) and 2.31 (LsCYP) (Fig. 5). The RTqPCR results showed that all candidate RGs gave results consistent with the data from the transcriptome database. Overall, the most suitable internal RGs chosen for use in leaves were $L s W D, L s G A P D H$ and $L s H 3$ and those for fruits were $L s H 3, L s G A P D H, L s P 4 H$ and $L s C Y P$.

\section{DISCUSSION}

RT-qPCR, as one of the most commonly used and important tools for gene expression analysis, is characterized by rapidity and efficiency, responsiveness, simplicity in operation, high throughput, and specificity (Huggett et al., 2005; Liu et al., 2012). RT-qPCR can be used for qualitative or quantitative analysis of gene expression differences, and the appropriate internal RGs for relative quantitative analysis of the expression of genes are essential. Recent studies indicate that there is no single internal reference gene that is absolutely stable and therefore the choice of internal reference gene depends upon the various experimental conditions (Radonić et al., 2014; Ceelen et al., 2014; Kong et al., 2014). The ideal internal reference gene should be stably expressed under the corresponding experimental conditions, and its expression level should not be too high or too low; moreover, it should not be a pseudogene and its expression level should not be associated with the cell cycle. With continuous improvement in RT-qPCR requirements, researchers choose two or more RGs for gene analysis in order to reduce the error and obtain more reliable results (Liu et al., 2012; Kong et al., 2016).

In recent years, transcriptome sequencing technology has been widely used in various fields of molecular biology. The rapid development of transcriptome technology provides a better understanding of gene expression in plant samples from specific tissue, at different developmental stages, or under stress conditions. Transcriptome analysis based on high throughput sequencing can help us to quickly understand the differences in gene expression 
368 levels in plant tissue under specific conditions and can also be used to analyze the expression 369 abundance of transcripts, identify the variable splicing of genes, determine the location of 370 transcription, investigate gene fusion events, and discover new transcripts and other important 371 information. In the screening of plant internal RGs, transcriptome sequencing analysis also 372 provides us with a new screening pathway (Huggett et al., 2005).

373 We performed RNA-Seq for CGMMV-infected bottle gourd, and the genes that were not 374 differentially expressed were selected as the candidate RGs based on the transcriptome data. 375 Certain parameters were set to screen the stable expression genes as candidate RGs from RNA376 seq data, and some traditional RGs were also compared to identify the most suitable candidate 377 RGs for leaves or fruits, separately. Among them, LsH3 and LsWD were selected from the RNA378 seq as candidate RGs in the CGMMV-infected leaves and fruits of bottle gourd. H3 is one of the 379 most important constituents of chromatin, and its amino acid sequence is highly conserved. 380 Methylation and acetylation of Histone $H 3$ play an important role in the growth and development 381 of plants (Bortoluzzi et al., 2017; Wollmann et al., 2017; Ingouff et al., 2010). Tryptophan and 382 aspartic acid (WD)-repeat protein is a class of proteins that contain multiple highly conserved 383 WD motifs and are strongly conserved. It is the Gb subunit of heterotrimeric G proteins, which 384 forms a tight dimer ( $\mathrm{Gbg}$ ) with $\mathrm{Gg}$ subunits and plays an important role in signal transduction, 385 protein transport, and RNA processing (Smith et al., 1999; Li et al., 2014; Van et al., 2003; 386 Gachomo et al., 2014). Both LsH3 and LsWD genes were then compared with 14 genes used 387 traditionally in cucurbitaceous crops to select the most suitable RGs in different bottle gourd 388 tissues under CGMMV infection. Both geNorm and NormFinder analysis suggested that the two novel genes $L s W D$ and $L s H 3$ selected from our RNA-Seq data are suitable candidates to use in evaluating the gene expression stability in bottle gourd leaves and fruits infected by CGMMV. The further RefFinder analysis suggested that $L s W D, L s G A P D H$ and $L s H 3$ were the best three common optimal RGs for both leaves and fruits whether infected by CGMMV or not. Of the commonly used traditional RGs, $L s G A P D H$ was the most stable in both leaves and fruits under CGMMV infection, but the novel $L s W D$ reference gene ranked in first place.

Several other novel RGs selected from the RNA-seq data and some traditional RGs were also compared to identify the most suitable candidate RGs for leaves or fruits, separately. geNorm and NormFinder analysis, and the BestKeeper analysis based on these two algorithms were consistent with each other with a slight difference, and a web-based comprehensive analysis tool RefFinder combined these analyses and suggested that the top three candidate RGs screened from bottle gourd leaves were $L s C Y P, L s H 3$ and $L s T B P$, while those in fruits were $L s P 4 H$, $L s A D P$, and $L s T B P$. These should be the best RGs to use in RT-qPCR.

IPT is an important rate-limiting enzyme in the synthesis of cytokinin (CTK), catalyzing the decomposition of isopentenyl pyrophosphate and adenosine monophosphate to produce isoforms as precursors of CTK (i.e., monopentenyl AMP, iAMP), which can promote the increase in CTK content in plant cells (Hwang et al., 2006; Zhu et al., 2012). The expression of the IPT gene in plants can improve stress resistance (Reguera et al., 2013; Žižková et al., 2015), delay leaf senescence, and improve defence against insect pests (Smigocki et al., 1993; Novák et al.,2013). DdRP is an essential enzyme for the replication of transcription systems in a variety of 
organisms and plays an important role in controlling transcription during gene expression (Wnendt et al., 1990; Knopf, 1998). These two genes were selected to validate the applicability of the screened RGs from bottle gourd in response to CGMMV. According to the comprehensive analysis, $L s T B P, L s W D, L s H 3, L s G A P D H$ and $L s C Y P$ were selected to as RGs in leaf, and all these genes with $L s P 4 H$ were used to analyze $I P T$ and $D d R P$ expression in fruit. RT-qPCR results combined with transcriptome analysis showed a consistent trend of expression, which indicated that the candidate RGs were stable. Among these genes, $L s W D, L s G A P D H$ and $L s H 3$ were most suitable as internal RGs in the leaf, and $L s H 3, L s G A P D H, L s P 4 H$ and $L s C Y P$ as those for the fruit. Therefore, the novel genes $L s H 3$ and $L s W D$ were more stable both in leaves and in fruits under CGMMV infection than the previous reference genes, such as $C Y P, G A P D H$, and $T B P$, although among the traditional RGs, GAPDH showed its superiority both in leaves and in fruits under CGMMV infection.

For the limitation that the RNA-Seq data was only from one bottle gourd variety infected with CGMMV, we further analysis the existence of these RGs in different bottle gourd genotypes, and found all these RGs are existed in about 50 different type of bottle gourd with different fruit shape according to the resequencing data we could access, and the single nucleotide polymorphism (SNP) analysis about the sequences of these RGs amplified with the primers we designed, most are very conserved with no variation, only four RGs ( $L s X R N 1, L s U B C, L s C Y P$, $L s T U A$ ) had slight variation. The SNP analysis further suggest the covservation of these RGs in different bottle gourd type. These selected RGs for bottle gourd leaves and fruits lay the foundation for further related research.

\section{CONCLUSIONS}

In this study, 16 candidate RGs of both leaf and fruit and 18 candidate RGs mostly from separate RNA-Seq datasets of bottle gourd leaf or fruit were assessed for their potential use as RGs in bottle gourd. Reliable normalized analysis by geNorm, NormFinder, BestKeeper and RefFinder indicated that $L s W D, L s G A P D H$ and $L s H 3$ were the most optimal RGs for bottle gourd leaves, and $L s H 3, L s G A P D H, L s P 4 H$ and $L s C Y P$ for the fruit. The candidate RGs provided in this study could be used to normalize the target genes in bottle gourd leaves and fruits to improve the accuracy and reliability of gene expression studies and the further related studies.

\section{ACKNOWLEDGMENTS}

We would like to thank Prof. M. J. Adams, Rothamsted Research, Harpenden, Herts, UK for correcting the English of the manuscript.

\section{Figure legends}


450 Figure 1 Expression intensity of candidate RGs in healthy control and CGMMV-infected 451 samples of bottle gourd. (A) bottle gourd leaves indicated in blue color. (B) bottle gourd fruits 452 indicated in red color. (C) bottle gourd leaves and fruits indicated in green color. Values are 453 given as $\mathrm{Cq}$ (mean of triplicate samples) and are inversely proportional to the amount of template. 454 The box indicates the 25 th and 75 th percentiles. Whiskers represent the maximum and minimum

Figure 2 Characteristic expression of the universal genes in bottle gourd under CGMMV infection. (A) A heatmap was used to visualize the expression pattern of the two novel candidate RGs selected from RNA-Seq data and 14 commonly used RGs under CGMMV infection. (B) Expression levels and variations of the 16 common RGs under CGMMV infection.

Figure 3 Expression stability of the candidate RGs analyzed by geNorm. $M$ represents the stability value. M of RGs screened from RNA-Seq in both bottle gourd leaves and fruits (A), and $\mathrm{Vn} / \mathrm{Vn}+1$ of the universal RGs in both bottle gourd leaves and fruits (B) ; M of RGs screened from RNA-Seq in bottle gourd leaves (C), and $\mathrm{Vn} / \mathrm{Vn}+1$ of RGs screened from the RNA-Seq in bottle gourd leaves (D), $\mathrm{M}$ of RGs screened from RNA-Seq in bottle gourd fruits (E), and $\mathrm{Vn} / \mathrm{Vn}+1$ of the universal RGs in bottle gourd fruits $(\mathrm{F})$.

Figure 4 Expression stability of the candidate RGs analyzed by NormFinder. The samples were divided into two subgroups according to the method of leaf and fruit set. The histogram displays the intergroup variation. The error bars represent the intragroup variation. $M$ represents the stability value. Asterisks indicate the best genes. NormFinder analysis of candidate RGs screened from the RNA-Seq and the traditional RGs in both bottle gourd leaves and fruits (A), from the RNA-Seq in bottle gourd leaves (B), and in bottle gourd fruits (C).

Figure 5 Relative quantification of $L S I P T$ and $L s D d R P$ expression in gourd leaf and fruit infected by CGMMV with RGs selected. $L s T B P$ (leaf and fruit), $L s W D$ (leaf and fruit), $L s H 3$ (leaf and fruit), $L s G A P D H$ (leaf and fruit), $L s C Y P$ (leaf and fruit) and $L s P 4 H$ (fruit only) were used as RGs. Error bars represent mean standard error calculated from three biological replicates. A control mock-inoculated sample was used as the calibrator (=1). (A) LsIPT expression of gourd leaves with selected RGs. (B) $L s D d R P$ expression of gourd leaves with selected RGs. (C) $L S I P T$ expression of gourd fruits with selected RGs. (D) $L s D d R P$ expression of gourd fruits with selected RGs. L: leaf, F: fruit.

Table 1 Primer sequences and PCR amplification characteristics for commonly-used candidate RGs, LsIPT and $L s D d R P$.

Table 2 Primer sequences and PCR amplification characteristics for candidate RGs selected from bottle gourd RNA-seq database. 


\section{SUPPLEMENTARY MATERIAL}

Figure S1 Symptoms of CGMMV on $L$. siceraria and detection of CGMMV in systemic leaves and fruits of $\boldsymbol{L}$. siceraria. (A) The typical green mottle mosaic symptom on CGMMVinfected leaves 14 days after inoculation (right panel), while not symptom on mock leaves (left panel). (B) No obvious symptoms of virus on the fruit of CGMMV-infected bottle gourd (the bottom panel) and the mock fruits (the upper panel). (C) Detection of CGMMV(the upper panel), ZYMV(the middle panel) and WMV(the bottom panel) on L. siceraria by RT-PCR. (B) Detection of CGMMV by western blot.

Figure S2 Dissolution curves of candidate RGs. (A) Dissolution curves of candidate RGs on both leaf and fruit of bottle gourd. (B) Dissolution curves of candidate RGs on leaf of bottle gourd. (C) Dissolution curves of candidate RGs on fruit of bottle gourd.

Figure S3 PCR amplification products of all RGs in $2 \%$ agarose gel. The upper line "C", indicates the cDNA template, the bottom line " $G$ ", indicates the gDNA template. " $M$ " indicates the DNA ladder marker. (A) PCR amplification products of all RGs in L. siceraria leaf. (B) PCR amplification products of all RGs in L. siceraria fruit.

Table S1 Non-differentially expressed genes in the leaves of bottle gourd.

Table S2 Non-differentially expressed genes in the fruits of bottle gourd.

Table S3 The 11 most stably expressed genes in leaves screened from the RNA-seq dataset. The RPKM $>40, \mathrm{RPKMmax} / \mathrm{min}<2.0$, and $\mathrm{CV}<0.3, \mathrm{p}<0.05$. All the selected internal RGs have only one transcript.

Table S4 The 86 most stably expressed genes in fruits screened from the RNA-seq dataset. The RPKM $>40, \mathrm{RPKMmax} / \min <2.0$, and $\mathrm{CV}<0.2, \mathrm{p}<0.05$. All the selected internal RGs have only one transcript, and are ranked from small to large according to their RPKMmax/min values.

Table S5 The 2 most stably expressed genes in both leaves and fruits in bottle gourd screened from the RNA-seq dataset. The RPKM $>40, \operatorname{RPKMmax} / \min <2.0$, and $\mathrm{CV}<0.2, \mathrm{p}<$ 0.05. All the selected internal RGs have only one transcript.

Table S6 The results of the transcriptome data screening from fourteen different of cucurbitaceous crops.

Table S7 Ranking of the candidate RGs in bottle gourd leaves and fruits separately screened from the RNA-Seq dataset according to their stability value using Bestkeeper and RefFinder analysis. 
532

533

534

535

536

537

538

539

540

541

542

543

544

545

546

547

548

549

550

551

552

553

554

555

556

557

558

559

560

561

562

563

564

565

566

567

568

569

570

571

572

Table S8 The data of $L s I P T$ and $L s D d R P$ from the RNA-seq database.

\section{REFERENCES}

Wang,Y., Xu,P., Wu, X., Wu, X., Wang, B., Huang, Y., Hu, Y., Lin, J., Lu, Z., Li, G.. 2018. GourdBase: a genome-centered multi-omics database for the bottle gourd (Lagenaria siceraria), an economically important cucurbit crop. Sci. Rep 8 : 3604 DOI: 10.1038/s41598-018-22007-3.

Decker-Walters, D. S., Wilkins-Ellert, M., Chung, S. M., \& Staub, J. E. 2004. COVER ARTICLE: discovery and genetic assessment of wild gottle gourd [Lagenaria Siceraria (Mol.) Standley; Cucurbitaceae] from zimbabwe. Econ. Bot 58: 501-508 DOI 10.1663/0013-0001(2004)058[0501:DAGAOW]2.0.CO; 2.

Yetisir, H., Sari, N.. 2013. Effect of different rootstock on plant growth yield and quality of watermelon. Aust. J. Exp. Agr 43: 1269-1274 DOI 10.1071/EA02095.

Cho, S. H., Joung, Y. H., Karna, S., Lee, H. E., Kim, J. H., Kim, J. H., Kim, J. H., Kim, D. S., Ahn, Y.K.. 2017. The development of cold resistance rootstock using Agrobacterium-mediated transformation of Arabidopsis CBF3/DREB1A, in bottle gourd (Lageneraria siceraria, Standl.). Sci. Hortic 214: 141-146 DOI 10.1016/j.scienta.2016.11.017.

Spalholz, H., Kubota, C. 2017. Rootstock affected in-and poststorage performance of grafted watermelon seedlings at low temperature. Horttechnology 27: 93-98 DOI 10.21273/HORTTECH03577-16.

Sharma, D., Goel, H. C., Chauhan, S. 2016. Radioprotective potential of Lagenaria siceraria extract against radiation induced gastrointestinal injury. Appl. Physiol. Nutr. Me 41: 1248-1254 DOI 10.1139/apnm-2016-0136.

Vigneshwaran, V., Thirusangu, P., Madhusudana, S., Krishna, V., Pramod, S. N., Prabhakar, B. T.. 2016. The latex sap of the 'Old World Plant' Lagenaria siceraria with potent lectin activity mitigates neoplastic malignancy targeting neovasculature and cell death. Int. Immunopharmacol 39: 158-171 DOI 10.1016/j.intimp.2016.07.024.

Zheng, H., Xiao, C., Han, K., Peng, J., Lin, L., Lu, Y., Xie, L., Wu, X., Xu, P., Li, G., Chen, J., Yan, F.. 2015. Development of an agroinoculation system for full-length and GFP-tagged cDNA clones of cucumber green mottle mosaic virus. Arch. Virol 160: 2867-2872 DOI 10.1007/s0070.

Ugaki, M., Tomiyama, M., Kakutani, T., Hidaka, S., Kiguchi, T., Nagata, R., Sato, T., Motoyoshi, F., Nishiguchi, M.. 1991. The complete nucleotide sequence of cucumber green mottle mosaic virus (SH strain) genomic RNA. J. Gen. Virol 72: 1487-1495 DOI 10.1099/0022-1317-72-7-1487.

Sano, Y., Inoue, H., Kajiwara, K., Hiragi, Y., Isoda, S. 1997. Structural analysis of A-protein of cucumber green mottle mosaic virus and tobacco mosaic virus by synchrotron small-angle X-ray scattering. J. Protein Chem 16: 151-159 DOI 10.1023/A:102639821.

Tan, S. H., Nishiguchi, M., Murata, M., \& Motoyoshi, F. 2000. The genome structure of kyuri green mottle mosaic tobamovirus and its comparison with that of cucumber green mottle mosaic tobamovirus.Arch. Virol 145: 1067-1079 DOI 10.1007/s007050070.

Ali, A., Mohammad, O., \& Khattab, A. 2012. Distribution of viruses infecting cucurbit crops and isolation of potential new virus-like sequences from weeds in Oklahoma. Plant Dis 96: 243-248 DOI 10.1094/PDIS-05-110419.

Antignus, Y., Pearlsman, M., Ben-Yoseph, R., Cohen, S. 1990. Occurrence of a variant of cucumber green mottle mosaic virus in Israel. Phytoparasitica 18: 50-56 DOI 10.1007/ BF02980826. 
Slavokhotova, A. A., Andreeva, E. N., Shijan, A. N., Odintsova, T. I., Pukhalskij, V. A. 2007. Specifics of the coat protein gene in Russian strains of the cucumber green mottle mosaic virus. Russ. J. Gente 43: 1221-1226 DOI 10.1134/S1022795407110038.

Varveri, C., Vassilakos, N., Bem, F. 2002. Characterization and detection of cucumber green mottle mosaic virus, in Greece. Phytoparasitica 30: 493-501 DOI 10.1007/BF02979754.

Ali, A., Natsuaki, T., \& Okuda, S. 2004. Identification and molecular characterization of viruses infecting cucurbits in Pakistan. J. Phytopathol 152: 677-682 DOI 10.1111/j.1439-0434.2004.00915.x.

Amer, M. A. 2015. Biological and molecular characterization of cucumber green mottle mosaic virus affecting bottle gourd and watermelon plants in Saudi Arabia. Int. J. Agric. Biol 17: 748-754.

Liu, H., Luo, L., Liang, C., Jiang, N., Liu, P., Li, J.. 2015. High-throughput sequencing identifies novel and conserved cucumber (Cucumis sativus L.) microRNAs in response to cucumber green mottle mosaic virus infection. Plos. One 10: e0129002 DOI 10.1371/journal.pone.0129002.

Li, J., Zheng, H., Zhang, C., Han, K., Wang, S., Peng, J., Lu, Y., Zhao, J., Xu, P., Wu, X., Li, G., Chen, J., Yan, F. 2016. Different virus-derived siRNAs profiles between leaves and fruits in cucumber green mottle mosaic virus-infected Lagenaria siceraria plants. Front. Microbiol 7: 1797 DOI 10.3389/fmicb.2016.01797.

Sun, Y., Niu, X., Fan, M. 2017. Genome-wide identification of cucumber green mottle mosaic virus-responsive microRNAs in watermelon. Arch. Virol 162: 2591-2602 DOI 10.1007/s00705-017-3401-6.

Radonić, A., Thulke, S., Mackay, I. M., Landt, O., Siegert, W., Nitsche, A. 2014. Guideline to reference gene selection for quantitative real-time PCR. Biochem. Bioph. Res. Co 313: 856-862 DOI 10.1016/j.bbrc.2003.11.177.

Huggett, J., Dheda, K., Bustin, S., Zumla, A. 2005. Real-time RT-PCR normalisation; strategies and considerations. Genes. Immun 6: 279-284 DOI 10.1038/sj.gene.6364190.

Ceelen, L., De Craene, J., De Spiegelaere, W. 2014. Evaluation of normalization strategies used in real-time quantitative PCR experiments in HepaRG cell Line studies. Clin. Chem 60: 451-454 DOI 10.1373/clinchem.2013.209478.

Kong, Q., Gao, L., Cao, L., Liu, Y., Saba, H., Huang, Y., Bie, Z.. 2016. Assessment of suitable reference genes for quantitative gene expression studies in melon fruits. Front. Plant Sci 7: 1178 DOI 10.3389/fpls.2016.01178.

Kong, Q., Yuan, J., Niu, P., Xie, J., Jiang, W., Huang, Y., Bie, Z.. 2014. Screening suitable reference genes for normalization in reverse transcription quantitative real-time PCR analysis in melon. Plos One 9: e87197 DOI 10.1371/journal.pone.0087197.

Wan, H., Zhao, Z., Qian, C., Sui, Y., Malik, A. A., Chen, J. 2010. Selection of appropriate reference genes for gene expression studies by quantitative real-time polymerase chain reaction in cucumber. Anal. Biochem 399: 257-61 DOI 10.1016/j.ab.2009.12.008.

Wang, L., Li, P., Wang, Z., Liu, J., Hu, J., Li, J. 2014. Identification and validation of suitable internal reference genes for SYBR-GREEN qRT-PCR studies during cucumber development. J. Hortic. Sci. Biotech 89: 312-320 DOI 10.1080/14620316.2014.11513085.

Warzybok, A., \& Migocka, M. 2013. Reliable reference genes for normalization of gene expression in cucumber grown under different nitrogen nutrition. Plos One 8: e72887 DOI 10.1371/journal.pone.0072887.

Sestili, S., Sebastiani, M. S., Belisario, A., Ficcadenti, N. 2014. Reference gene selection for gene expression analysis in melon infected by Fusarium oxysporum, f.sp. melonis. J. Plant Biochem. Bito 23: 238-248 DOI 10.1007/s13562-013-0207-9. 
614 Wu, W., Deng, Q., Shi, P., Yang, J., Hu, Z., Zhang, M. 2016. Identification of appropriate reference genes for
615 normalization of miRNA expression in grafted watermelon plants under different nutrient stresses. Plos One 11:

615

616

617

618

619

620

621

622

623

624

625

626

627

628

629

630

631

632

633

634

635

636

637

638

639

640

641

642

643

644

645

646

647

648

649

650

651

652

653

654 e0164725 DOI 10.1371/journal.pone.0164725.

Kong, Q., Yuan, J., Gao, L., Zhao, S., Jiang, W., Huang, Y., Bie, Z.. 2014. Identification of suitable reference genes for gene expression normalization in qRT-PCR analysis in watermelon. Plos One 9: e90612 DOI 10.1371/journal.pone.0090612.

Kong, Q., Yuan, J., Gao, L., Zhao, L., Cheng, F., Huang, Y., Bie, Z.. 2015. Evaluation of appropriate reference genes for gene expression normalization during watermelon fruit development. Plos One 10: e0130865 DOI 10.1371/journal.pone.0130865.

Liu, D., Shi, L., Han, C., Yu, J., Li, D., Zhang, Y. 2012. Validation of reference genes for gene expression studies in virus-infected Nicotiana benthamiana using quantitative real-time PCR. Plos One 7: e46451 DOI 10.1371/journal.pone.0046451.

Kudo, T., Sasaki, Y., Terashima, S., Matsuda-Imai, N., Takano, T., Saito, M., Kanno, M., Ozaki, S., Suwabe, K., Suzuki, G., Watanabe, M., Matsuoka, M., Takayama, S., Yano, K.. 2016. Identification of reference genes for quantitative expression analysis using large-scale RNA-seq data of Arabidopsis thaliana and model crop plants. Genes Genet. Syst 2: 72-74 DOI 10.1266/ggs.15-00065.

Guo, H., Jiang, L., Xia, Q. 2016. Selection of reference genes for analysis of stress-responsive genes after challenge with viruses and temperature changes in the silkworm Bombyx mori. Mol. Genet. Genomice 291: 9991004 DOI 10.1007/s00438-015-1125-4.

Marcolino-Gomes, J., Rodrigues, F. A., Fuganti-Pagliarini, R., Nakayama, T. J., Reis, R. R., Farias, J. R. B., Harmon, F. G., Molinari, H. B. C., Molinari, M. D. C., Nepomuceno, A.. 2015. Transcriptome-wide identification of reference genes for expression analysis of soybean responses to drought stress along the day. Plos One 10: e0139051 DOI 10.1371/journal.pone.0139051.

Zhang, Z., Jhaveri, D. J., Marshall, V. M., Bauer, D. C., Edson, J., Narayanan, R. K., Robinson, G. J., Lundberg, A. E., Bartlett, P. F., Wray, N. R., Zhao, Q. Y.. 2014. A comparative study of techniques for differential expression analysis on RNA-Seq data. Plos One 9: e103207 DOI 10.1371/journal.pone.0103207.

Liu, X., Guan, H., Song, M., Fu, Y., Han, X., Lei, M., Ren, J., Guo, B., He,W., Wei,Y.. 2018. Reference gene selection for qRT-PCR assays in Stellera chamaejasme subjected to abiotic stresses and hormone treatments based on transcriptome datasets. Peerj 6: e4535 DOI 10.7717/peerj.4535.

Heeju, L., Mikyeong, K., Sanggyu, L., Changsun, C., Hongsoo, C., Haeryun, K., Gugseoun, C., Changhoo, C.. 2015. Physiological characteristics of melon plants showing leaf yellowing symptoms caused by CABYV infection. Kor.J.Hort.Sci.Technol 33(2): 210-218 DOI 10.7235/hort.2015.14149

Vandesompele, J., De Preter, K., Pattyn, F., Poppe, B., Van Roy, N., De Paepe, A., Speleman, F.. 2002. Accurate normalization of real-time quantitative RT-PCR data by geometric averaging of multiple internal control genes. Genome Boil 3: research0034-1 DOI 10.1186/gb-2002-3-7-research0034.

Andersen, C. L., Jensen, J. L., Ørntoft, T. F. 2004. Normalization of real-time quantitative reverse transcriptionPCR data: a model-based variance estimation approach to identify genes suited for normalization, applied to bladder and colon cancer data sets. Cancer Res 64: 5245-5250 DOI 10.1158/0008-5472.CAN-04-0496.

Pfaffl, M. W., Tichopad, A., Prgomet, C., Neuvians, T. P. 2004. Determination of stable housekeeping genes, differentially regulated target genes and sample integrity: BestKeeper-Excel-based tool using pair-wise correlations. Biotechnol. Lett 26: 509-515 DOI 0.1023/B:BILE.0000019559.84305.47. 
655

656

657

658

659

660

661

662

663

664

665

666

667

668

669

670

671

672

673

674

675

676

677

678

679

680

681

682

683

684

685

686

687

688

689

690

691

692

693

694

Bortoluzzi, A., Amato, A., Lucas, X., Blank, M., Ciulli, A. 2017. Structural basis of molecular recognition of helical histone H3 tail by PHD finger domains. Biochem J 474: 1633-1651 DOI 10.1042/BCJ20161053.

Wollmann, H., Stroud, H., Yelagandula, R., Tarutani, Y., Jiang, D., Jing, L., Jamge, B., Takeuchi, H., Holec, S., Nie, X., Kakutani, T., Jacobsen, SE., Berger, F.. 2017. The histone H3 variant H3.3 regulates gene body DNA methylation in Arabidopsis thaliana. Genome Biol 18: 94 DOI 10.1186/s13059-017-1221-3.

Ingouff, M., Rademacher, S., Holec, S., Šoljić, L., Xin, N., Readshaw, A., Foo, S.H., Lahouze, B., Sprunck, S., Berger, F.. 2010. Zygotic resetting of the HISTONE 3 variant repertoire participates in epigenetic reprogramming in Arabidopsis. Curr. Biol 20: 2137-2143 DOI 10.1016/j.cub.2010.11.012.

Smith, T. F., Gaitatzes, C., Saxena, K., Neer, E. J. 1999. The WD repeat: a common architecture for diverse functions. Trends Biochem. Sci 24: 181-185 DOI 10.1016/S0968-0004(99)01384-5.

Li, Q., Zhao, P., Li, J., Zhang, C., Wang, L., Ren, Z. 2014. Genome- ${ }^{-}$ide analysis of the WD-repeat protein family in cucumber and Arabidopsis. Mol. Genet Genomics 289: 103-124 DOI 10.1007/s00438-013-0789-x.

Van Nocker, S., Ludwig, P. 2003. The WD-repeat protein superfamily in Arabidopsis: conservation and divergence in structure and function. BMC Genomics 4: 50 DOI 10.1186/1471-2164-4-50.

Gachomo, E. W., Jimenez-Lopez, J. C., Baptiste, L. J., Kotchoni, S. O. 2014. GIGANTUS1 (GTS1), a member of Transducin/WD40 protein superfamily, controls seed germination, growth and biomass accumulation through ribosome-biogenesis protein interactions in Arabidopsis thaliana. BMC Plant Bio 14: 37 DOI 10.1186/14712229-14-37.

Hwang, I., Sakakibara, H. 2006. Cytokinin biosynthesis and perception. Physiol. Plantarum 126: 528-538. DOI 10.1111/j.1399-3054.2006.00665.x.

Zhu, Y., Jin, Y., Wei, S., Li, H., Zhang, W.. 2012. Functional analysis of the isopentenyltransferase gene MdIPT3a from apple (Malus pumila Mill.). J. Hortic. Sci. Biotech 87: 478-484 DOI 10.1080/14620316.2012.11512898.

Reguera, M., Peleg, Z., Abdel-Tawab, Y. M., Tumimbang, E. B., Delatorre, C. A., Blumwald, E. 2013. Stressinduced cytokinin synthesis increases drought tolerance through the coordinated regulation of carbon and nitrogen assimilation in rice. Plant Physiol 163: 1609-1622 DOI 10.1104/pp.113.227702.

Žižková, E., Dobrev, P. I., Muhovski, Y., Hošek, P., Hoyerová, K., Haisel, D., Procházková, D., Lutts, S., Motyka, V., Hichri, I.. 2015. Tomato (Solanum lycopersicum L.) SIIPT3 and SIIPT4 isopentenyltransferases mediate salt stress response in tomato. BMC Plant Biol 15: 85 DOI 10.1186/s12870-015-0415-7.

Smigocki, A., Neal, J. W., McCanna, I., Douglass, L. 1993. Cytokinin-mediated insect resistance in Nicotiana plants transformed with the ipt gene. Plant Mol. Biol 23: 325-335 DOI 10.1007/BF00029008.

Novák, J., Pavlů, J., Novák, O., Nožková-Hlaváčková, V., Špundová, M., Hlavinka, J., Koukalová, Š., Skalák, J., ČernýBřetislav Brzobohatý, M.. 2013. High cytokinin levels induce a hypersensitive-like response in tobacco. Ann. Bot 112: 41-55 DOI 10.1093/aob/met092.

Wnendt, S., Hartmann, R. K., Ulbrich, N., Erdmann, V. A.. 1990. Isolation and physical properties of the DNA-directed RNA polymerase from Thermus thermophilus HB8. FEBS $J$ 191: 467-72 DOI 10.1111/j.14321033.1990.tb19145.x.

Knopf, C. W. 1998. Evolution of viral DNA-dependent RNA polymerases. Virus Genes 16: 47-58 DOI 10.1023/A:1007997609122. 


\section{Figure 1}

Expression intensity of candidate RGs in healthy control and CGMMV-infected samples of bottle gourd.

(A) bottle gourd leaves indicated in blue color. (B) bottle gourd fruits indicated in red color. (C) bottle gourd leaves and fruits indicated in green color. Values are given as $\mathrm{Cq}$ (mean of triplicate samples) and are inversely proportional to the amount of template. The box indicates the 25th and 75th percentiles. Whiskers represent the maximum and minimum values. The thin line within the box marks the median.

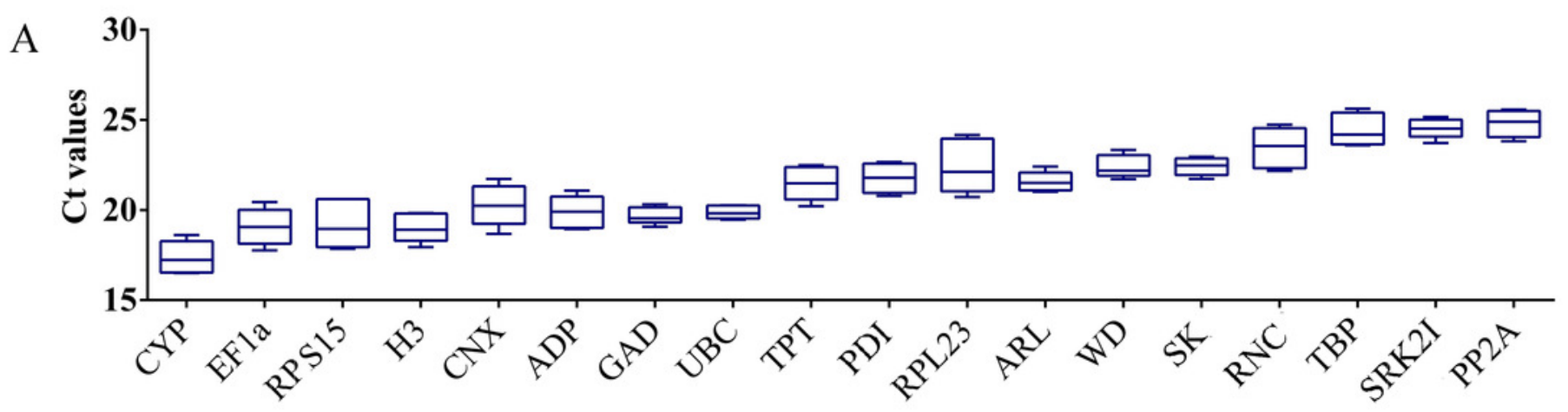

B

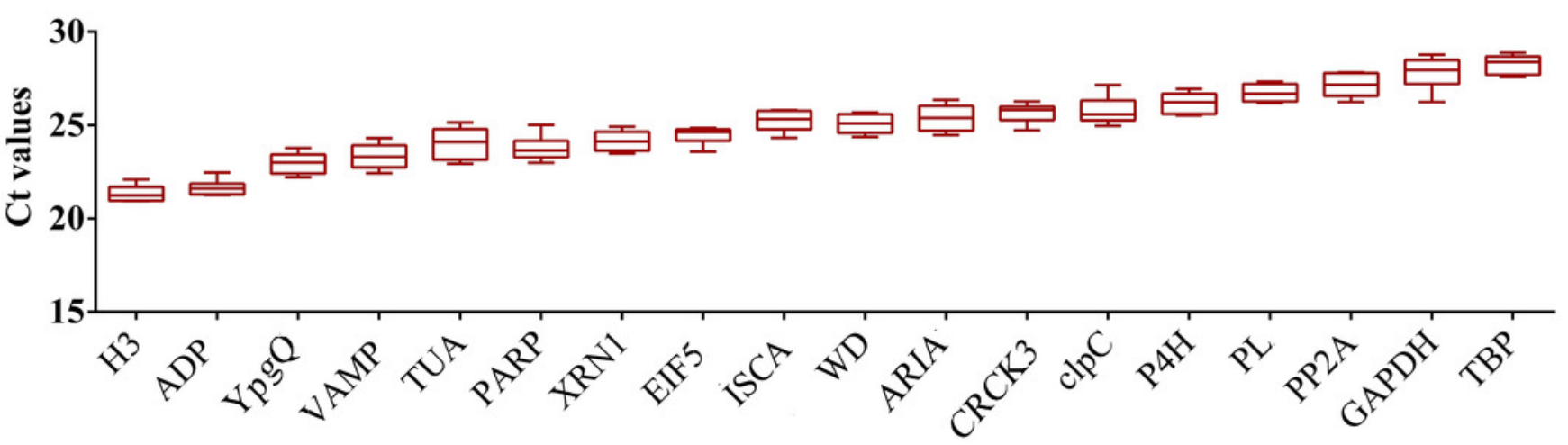

$\mathrm{C}$

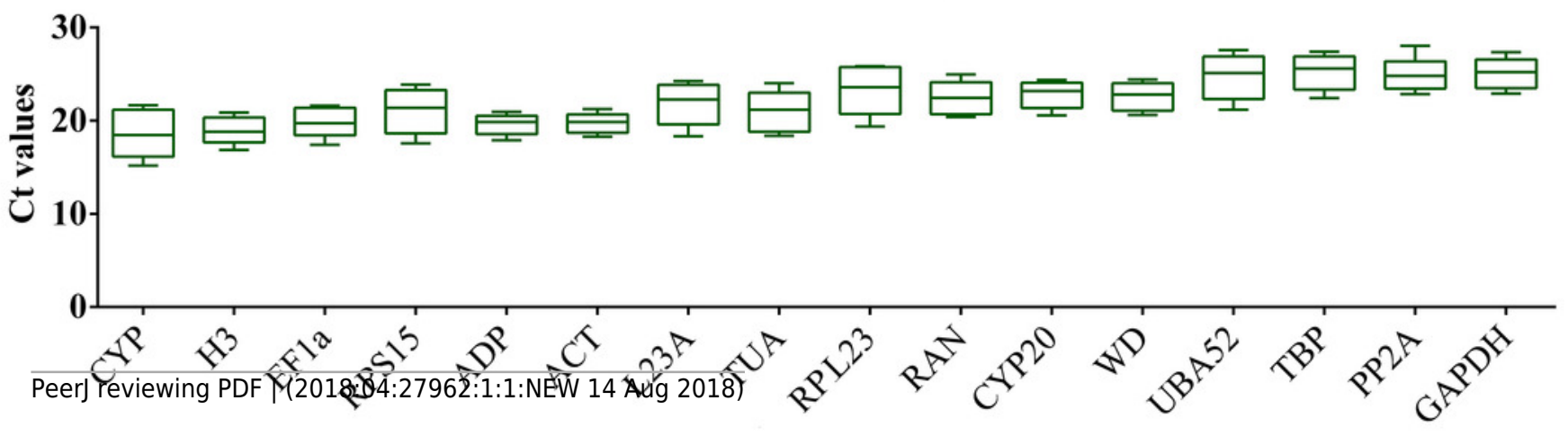


Figure 2

Characteristic expression of the universal genes in bottle gourd under CGMMV infection.

(A) A heatmap was used to visualize the expression pattern of the two novel candidate RGs selected from RNA-Seq data and 14 commonly used RGs under CGMMV infection. (B) Expression levels and variations of the 16 common RGs under CGMMV infection.
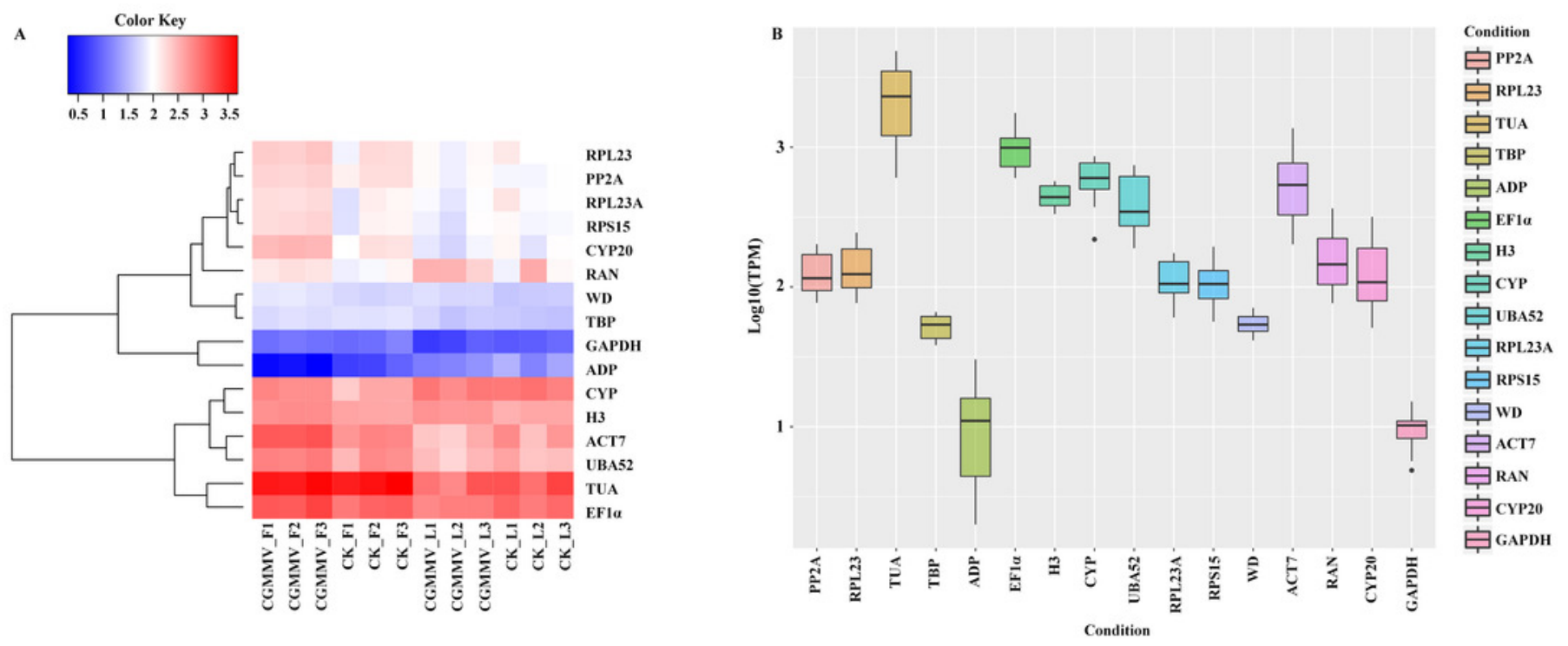


\section{Figure 3}

Expression stability of the candidate RGs analyzed by geNorm.

$M$ represents the stability value. M of RGs screened from RNA-Seq in both bottle gourd leaves and fruits (A), and $V n / V n+1$ of the universal RGs in both bottle gourd leaves and fruits (B); $M$ of RGs screened from RNA-Seq in bottle gourd leaves (C), and $V n / V n+1$ of RGs screened from the RNA-Seq in bottle gourd leaves (D), M of RGs screened from RNA-Seq in bottle gourd fruits $(E)$, and $V n / V n+1$ of the universal RGs in bottle gourd fruits (F).

A

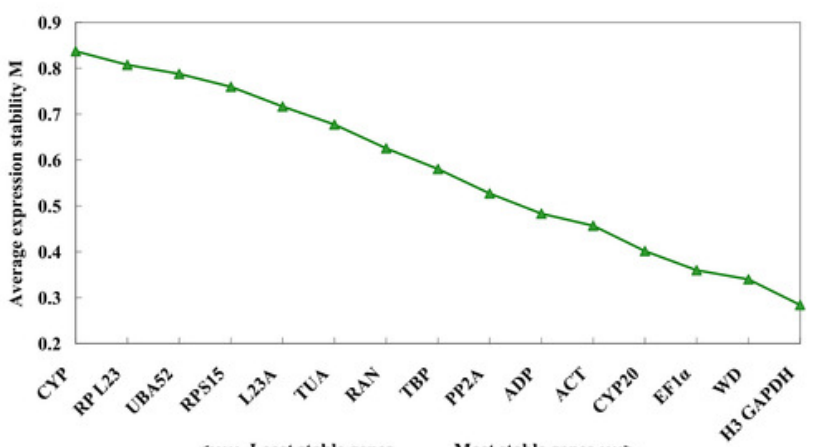

C

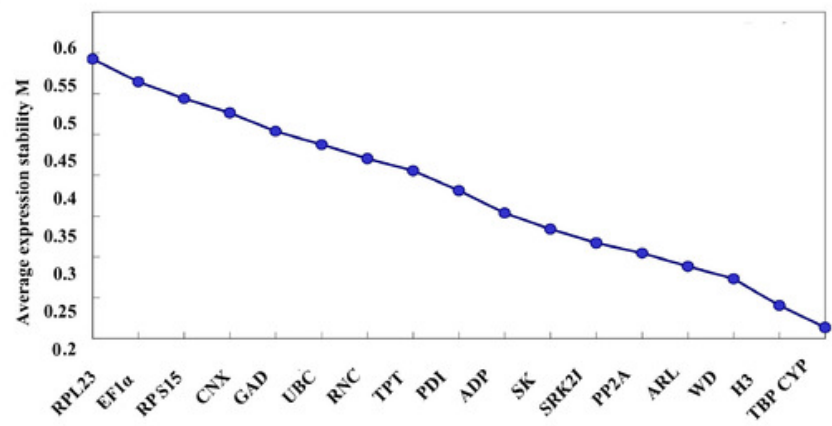

$<::::$ Least stable genes Most stable genes ::::>

$\mathbf{E}$

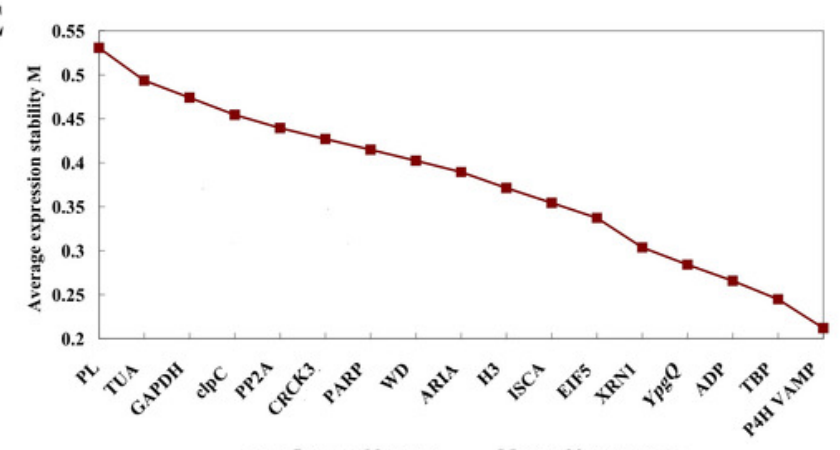

B

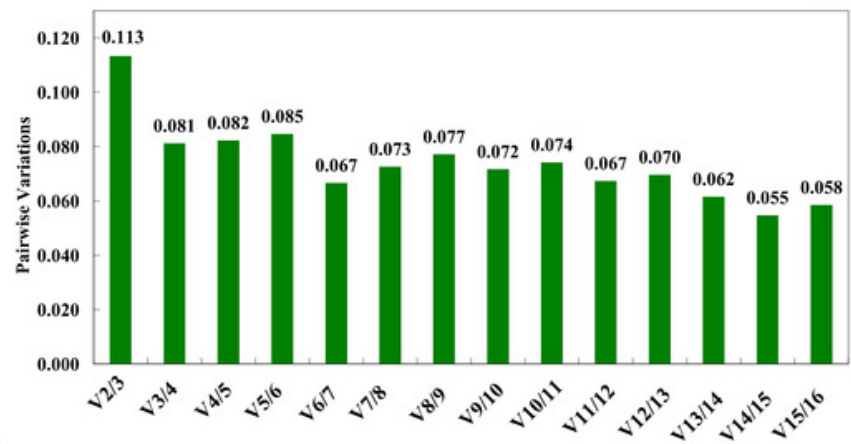

D

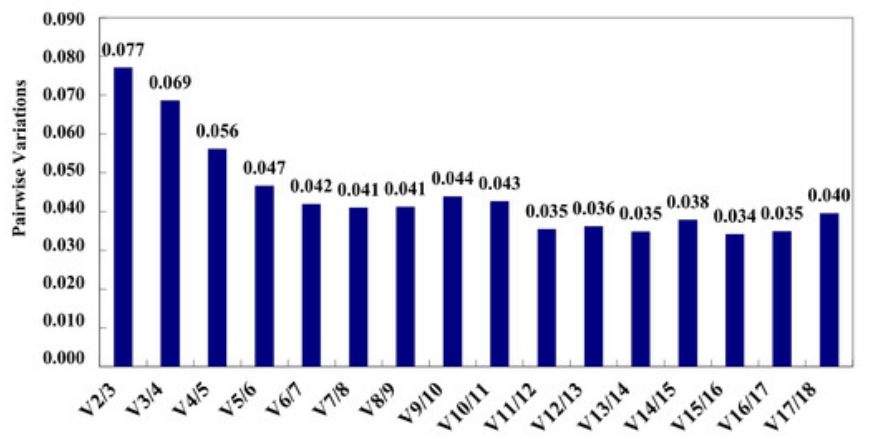

F

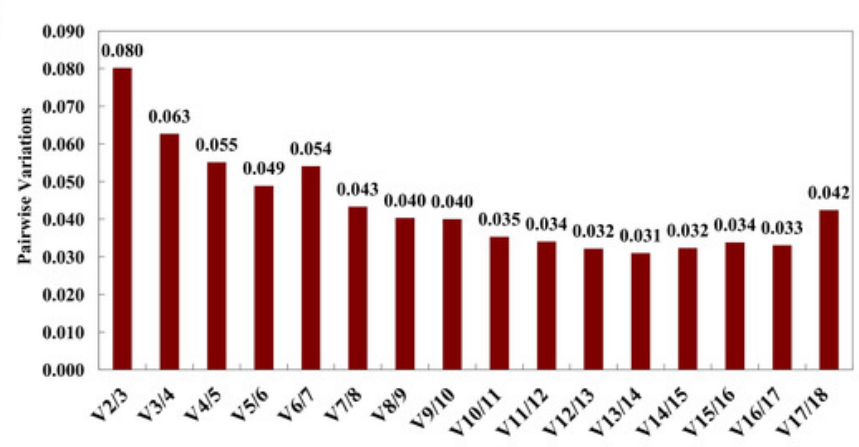




\section{Figure 4}

Expression stability of the candidate RGs analyzed by NormFinder.

The samples were divided into two subgroups according to the method of leaf and fruit set. The histogram displays the intergroup variation. The error bars represent the intragroup variation. $M$ represents the stability value. Asterisks indicate the best genes. NormFinder analysis of candidate RGs screened from the RNA-Seq and the traditional RGs in both bottle gourd leaves and fruits (A), from the RNA-Seq in bottle gourd leaves (B), and in bottle gourd fruits (C). 
A

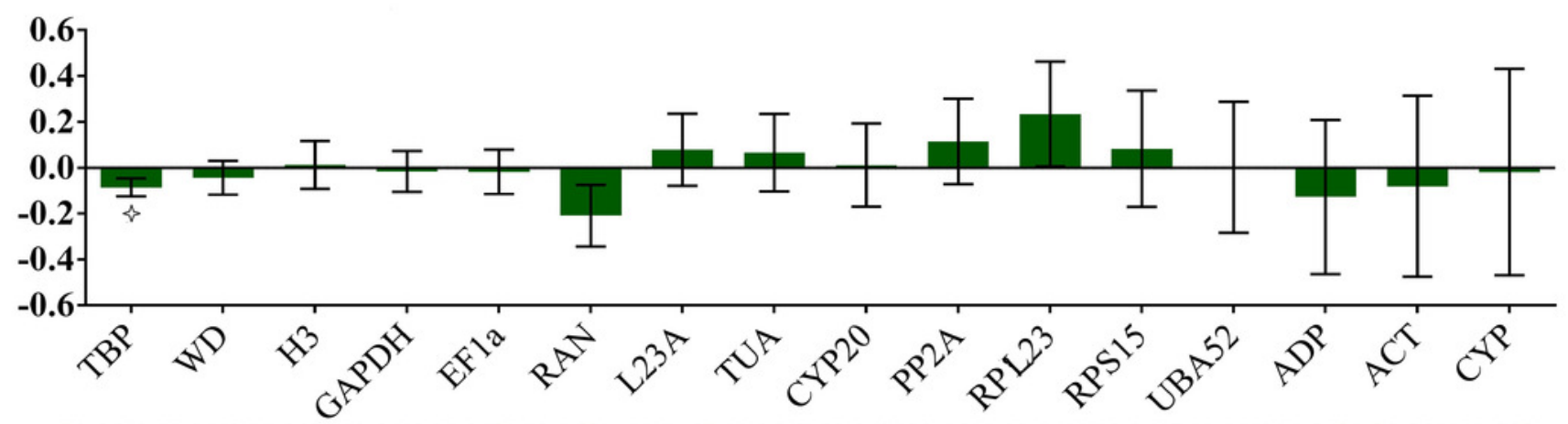

$\mathrm{M}=0.079 \mathrm{M}=0.103 \mathrm{M}=0.120 \mathrm{M}=0.121 \mathrm{M}=0.125 \mathrm{M}=0.144 \quad \mathrm{M}=0.145 \quad \mathrm{M}=0.167 \quad \mathrm{M}=0.171 \mathrm{M}=0.176 \quad \mathrm{M}=0.183 \quad \mathrm{M}=0.187 \mathrm{M}=0.203 \mathrm{M}=0.236 \quad \mathrm{M}=0.244 \mathrm{M}=0.273$

$\mathrm{B}$

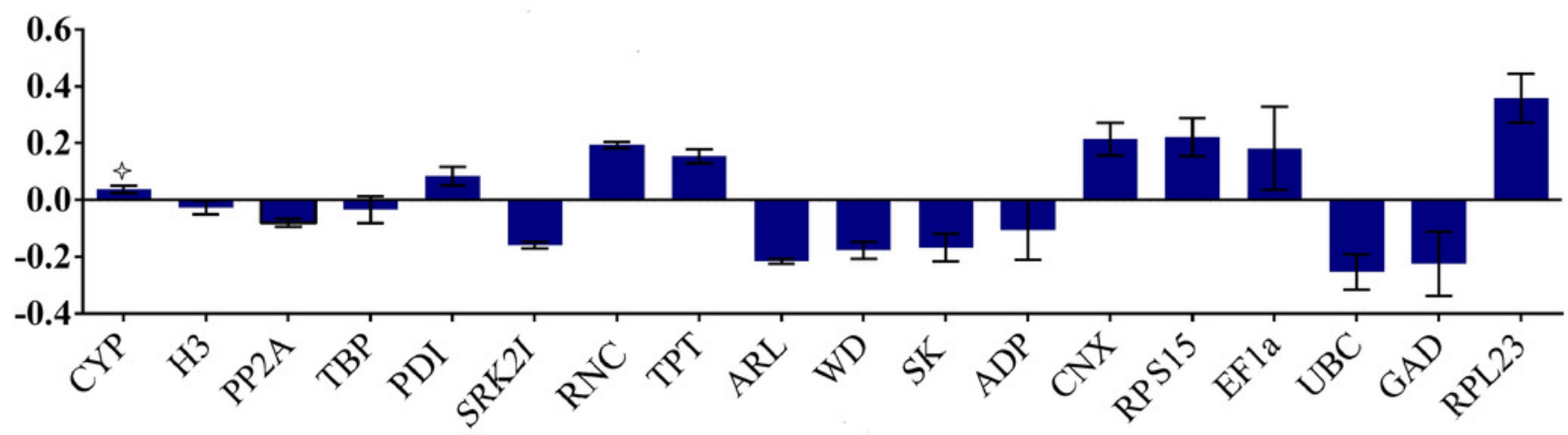

$\mathrm{M}=0.106 \mathrm{M}=0.122 \mathrm{M}=0.159 \mathrm{M}=0.166 \mathrm{M}=0.198 \mathrm{M}=0.234 \mathrm{M}=0.253 \mathrm{M}=0.259 \mathrm{M}=0.277 \mathrm{M}=0.281 \mathrm{M}=0.293 \mathrm{M}=0.300 \quad \mathrm{M}=0.399 \mathrm{M}=0.399 \quad \mathrm{M}=0.356 \mathrm{M}=0.369 \mathrm{M}=0.376 \mathrm{M}=0.446$

C'

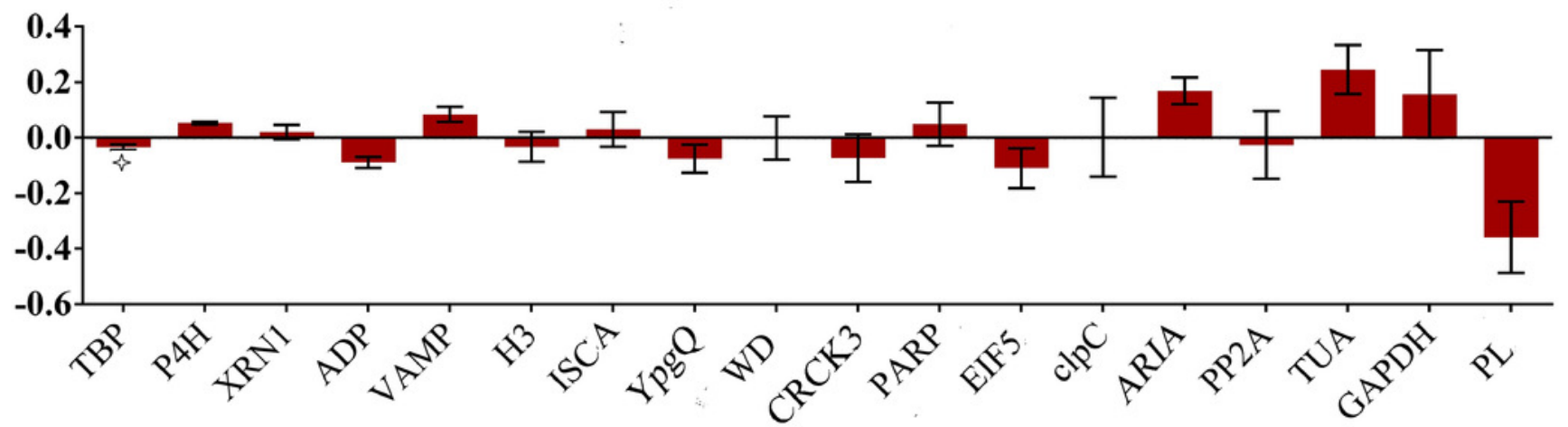

$\mathrm{M}=0.088 \mathrm{M}=0.095 \mathrm{M}=0.108 \mathrm{M}=0.138 \mathrm{M}=0.162 \mathrm{M}=0.167 \mathrm{M}=0.177 \mathrm{M}=0.183 \quad \mathrm{M}=0.183 \quad \mathrm{M}=0.188 \mathrm{M}=0.191 \mathrm{M}=0.209 \mathrm{M}=0.218 \quad \mathrm{M}=0.220 \quad \mathrm{M}=0.226 \mathrm{M}=0.259 \mathrm{M}=0.273 \mathrm{M}=0.299$ 


\section{Figure 5}

Relative quantification of $L S I P T$ and $L S D d R P$ expression in gourd leaf and fruit infected by CGMMV with RGs selected.

LsTBP (leaf and fruit), LsWD (leaf and fruit), LsH3 (leaf and fruit), LsGAPDH (leaf and fruit), LSCYP (leaf and fruit) and LsP4H (fruit only) were used as RGs. Error bars represent mean standard error calculated from three biological replicates. A control mock-inoculated sample was used as the calibrator (=1). (A) LSIPT expression of gourd leaves with selected RGs. (B) LsDdRP expression of gourd leaves with selected RGs. (C) LSIPT expression of gourd fruits with selected RGs. (D) LsDdRP expression of gourd fruits with selected RGs. L: leaf, F: fruit.

A

L-IPT expression
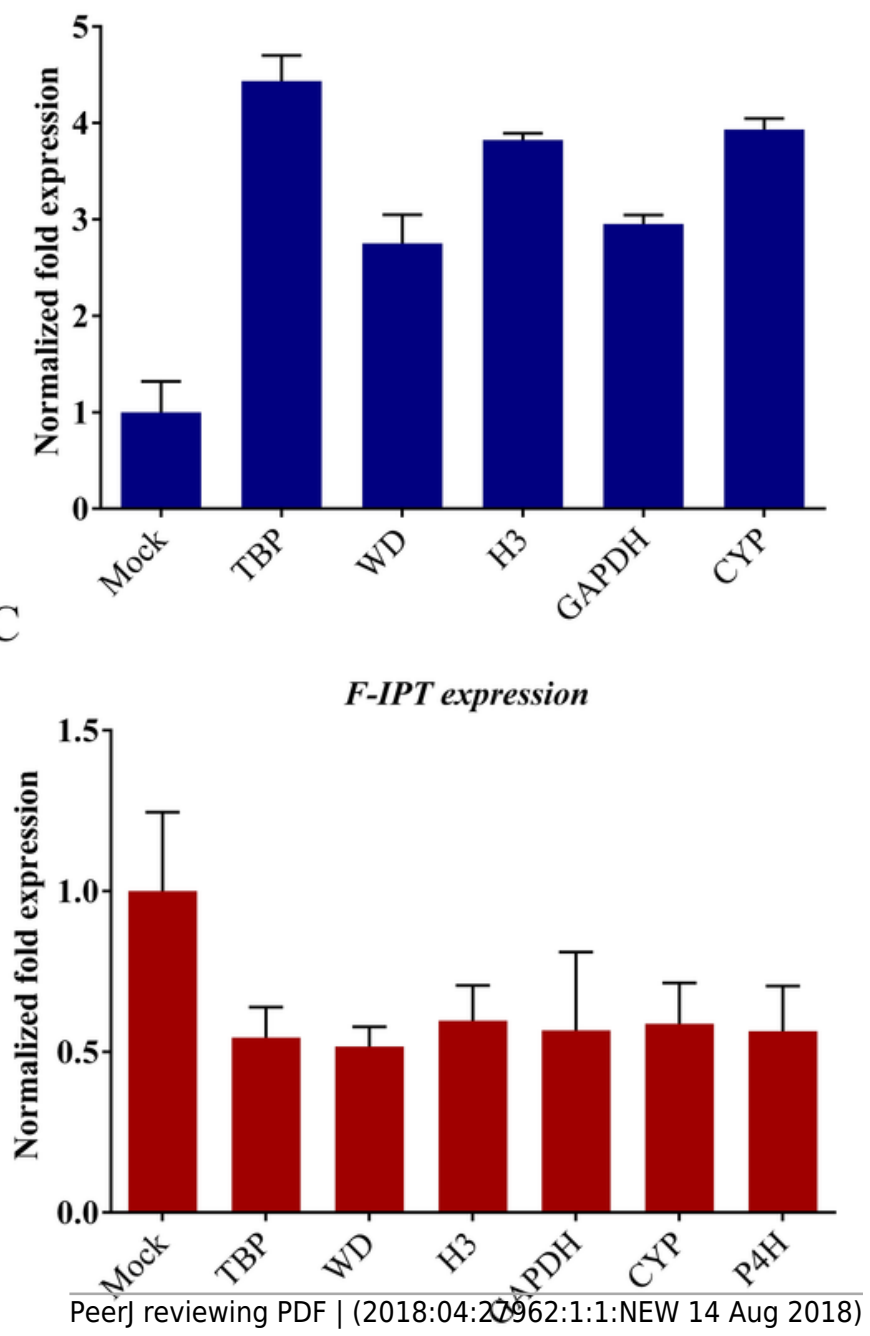

B

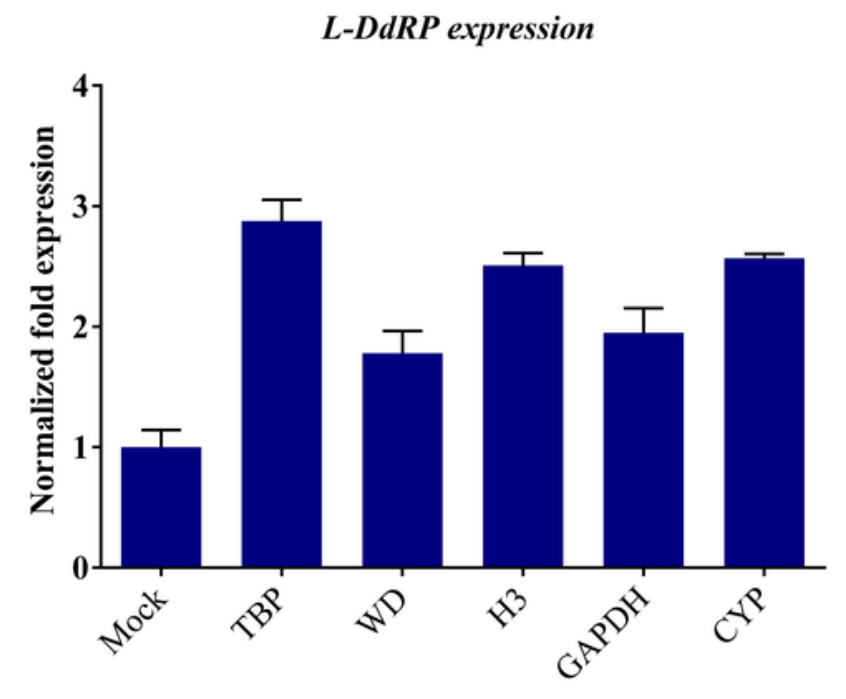

F-DdRP expression

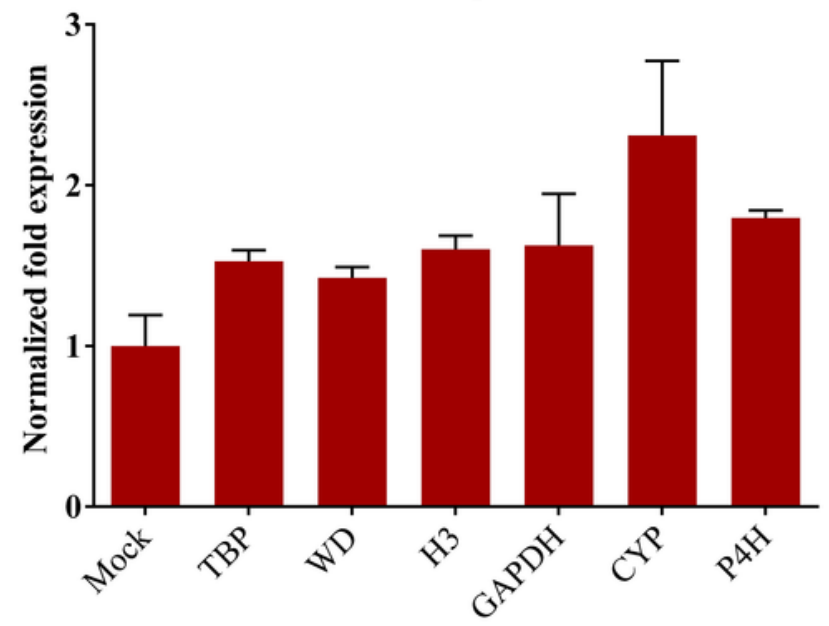




\section{Table 1 (on next page)}

Primer sequences and PCR amplification characteristics for commonly-used candidate RGs, LSIPT and LSDdRP. 
Table 1 Primer sequences and PCR amplification characteristics for commonly-used candidate reference genes, LsIPT and

\begin{tabular}{|c|c|c|c|c|c|c|c|c|c|c|}
\hline \multirow{2}{*}{$\begin{array}{l}\text { Gene } \\
\text { name }\end{array}$} & \multirow{2}{*}{ Description } & \multirow{2}{*}{$\begin{array}{c}\text { NCBI } \\
\text { Homolog locus }\end{array}$} & \multirow{2}{*}{$\begin{array}{l}\text { Gourdbase } \\
\text { Homolog locus }\end{array}$} & \multirow{2}{*}{$\begin{array}{l}\text { Forward primer Sequence/Reserve primer } \\
\text { sequenc }\left(5^{\prime}-3^{\prime}\right)\end{array}$} & \multirow{2}{*}{$\begin{array}{c}\text { Produ } \\
\text { ct } \\
\text { size } \\
\text { (bp) }\end{array}$} & \multirow{2}{*}{$\begin{array}{l}\text { Tm } \\
\left({ }^{\circ} \mathrm{C}\right. \\
)\end{array}$} & \multicolumn{2}{|c|}{ Leaf } & \multicolumn{2}{|c|}{ fruit } \\
\hline & & & & & & & E (\%) & $\mathbf{R}^{2}$ & E (\%) & $\mathbf{R}^{2}$ \\
\hline$L s H 3^{a, b}$ & histone $\mathrm{H} 3$ & LOC103494422 & BG_GLEAN_10002693 & CAAACTGCCCGTAAGTCCAC/GGCTTCTTCACTCCTCCTGT & 101 & $\begin{array}{c}81 . \\
9\end{array}$ & 110.06 & $\begin{array}{c}0.998 \\
0\end{array}$ & 103.67 & $\begin{array}{c}0.998 \\
6\end{array}$ \\
\hline$L s W D^{a, b}$ & WD repeat-containing protein & LOC101218407 & BG_GLEAN_10012213 & TCTGTGGTACTCGAGAAGGC/GAGAAATCTCCGGTGTGTCGT & 95 & $\begin{array}{c}82 . \\
5\end{array}$ & 106.96 & $\begin{array}{c}0.998 \\
7\end{array}$ & 103.13 & $\begin{array}{c}0.993 \\
7\end{array}$ \\
\hline LsACT & actin-7 & LOC103499652 & BG_GLEAN_10004800 & GGCAGTGGTTGTGAACATGT/CCCATGCTATCCTCCGTCTT & 98 & $\begin{array}{c}82 . \\
1\end{array}$ & 90.11 & $\begin{array}{c}0.998 \\
9\end{array}$ & 97.26 & $\begin{array}{c}0.999 \\
9\end{array}$ \\
\hline LsUBA52 & $\begin{array}{l}\text { ubiquitin-60S ribosomal protein } \\
\text { L40 }\end{array}$ & LOC101205082 & -- & AAGTGTGGACACAGCAACCA/GGGAAAGAGCCAAAAATAGG & 255 & $\begin{array}{c}79 . \\
3\end{array}$ & 94.86 & $\begin{array}{c}0.999 \\
0\end{array}$ & 116.23 & $\begin{array}{c}0.981 \\
6\end{array}$ \\
\hline LsRPL23a & $60 \mathrm{~S}$ ribosomal protein $\mathrm{L} 23$ & LOC101203845 & BG_GLEAN_10013074 & CATGACCATATCACCAACACAA/CGACAATACAGGAGCTAAGAA & 100 & $\begin{array}{c}77 . \\
3\end{array}$ & 98.16 & $\begin{array}{c}0.997 \\
8\end{array}$ & 97.15 & $\begin{array}{c}0.994 \\
2\end{array}$ \\
\hline LsRAN & Ran-GTPase & LOC111496316 & BG_GLEAN_10011129 & TCTACTGTTGGGATACCGCT/CAGAGATCACGATGCCATGTT & 145 & $\begin{array}{c}80 . \\
6\end{array}$ & 103.26 & $\begin{array}{c}0.997 \\
6\end{array}$ & 90.81 & $\begin{array}{c}0.996 \\
3\end{array}$ \\
\hline $\operatorname{LsPP2A^{a,b}}$ & $\begin{array}{l}\text { serine/threonine-protein } \\
\text { phosphatase PP2A catalytic subunit }\end{array}$ & LOC103502598 & BG_GLEAN_10010727 & $\begin{array}{l}\text { GGCAGATAACTCAAGTTTATGGA/GCTGTAAGAGGTAAATAATCAA } \\
\text { AGAGG }\end{array}$ & 109 & $\begin{array}{c}75 . \\
0\end{array}$ & 92.68 & $\begin{array}{c}0.999 \\
3\end{array}$ & 110.62 & $\begin{array}{c}0.993 \\
3\end{array}$ \\
\hline $\begin{array}{l}L S G A P D \\
H^{b}\end{array}$ & $\begin{array}{l}\text { Glyceraldehyde-3-phosphate } \\
\text { dehydrogenase }\end{array}$ & LOC103496285 & -- & CCCAGGGGATATCTGCAGGG/CATGGTGTTTTCAATGGAACCA & 109 & $\begin{array}{c}85 . \\
2\end{array}$ & 100.97 & $\begin{array}{c}0.998 \\
6\end{array}$ & 91.06 & $\begin{array}{c}0.993 \\
3\end{array}$ \\
\hline LSEFIa $a^{a}$ & Elongation factor $1-\alpha$ & LOC101215193 & -- & СTGCTTGCTCCTGCGTGAAA/CCACGATGTTGATGTGAATCTTCTC & 118 & $\begin{array}{c}83 . \\
9\end{array}$ & 105.42 & $\begin{array}{c}0.997 \\
7\end{array}$ & 103.34 & $\begin{array}{c}0.996 \\
2\end{array}$ \\
\hline LsADPa,b & ADP ribosylation factor & LOC101217563 & -- & ATATTGCCAACAAGGCGTAGA/TGCCCGTAAACAATGGACAAA & 92 & $\begin{array}{c}80 . \\
2\end{array}$ & 5.04 & $\begin{array}{c}0.996 \\
6\end{array}$ & 93.69 & $\begin{array}{c}0.996 \\
8\end{array}$ \\
\hline$L_{S T U A}^{b}$ & tubulin alpha & LOC103502708 & BG_GLEAN_10002510 & AGGACTGGGACGTACCGACA/CGGCTAATTTTCGCACTCGG & 145 & $\begin{array}{c}83 . \\
9\end{array}$ & 103.16 & $\begin{array}{c}0.990 \\
1\end{array}$ & 107.20 & $\begin{array}{l}0.996 \\
3\end{array}$ \\
\hline LsTBP,ab & $\begin{array}{l}\text { transcription initiation factor TFIID } \\
\text { TATA-box-binding protein }\end{array}$ & C103492411 & BG_GLEAN_10001318 & AAACTCTTCCCGCTTCCTCA/AGCCTTGATCTGCCATTCCT & 143 & $\begin{array}{c}81 . \\
3\end{array}$ & 93.79 & $\begin{array}{c}0.998 \\
7\end{array}$ & 96.90 & $\begin{array}{c}0.998 \\
6\end{array}$ \\
\hline LsRPSI $5^{a}$ & 40 S ribosomal protein $\mathrm{S} 15-4$ & LOC101217711 & BG_GLEAN_10016309 & AGTCCTCTTCTTCGGCACTC/TCCACTCGAAACCCTAGCAG & 135 & $\begin{array}{c}80 . \\
2\end{array}$ & 90.16 & $\begin{array}{c}0.998 \\
8\end{array}$ & 92.14 & $\begin{array}{c}0.999 \\
9\end{array}$ \\
\hline LsCYP20 & $\begin{array}{l}\text { peptidyl-prolyl cis-trans isomerase } \\
\text { CYP20-1 }\end{array}$ & LOC101213040 & BG_GLEAN_10005366 & TTTACCCTCGGCGATGGAAG/TGTGAACCATTTGTATCTGGA & 134 & $\begin{array}{c}80 . \\
8\end{array}$ & 96.15 & $\begin{array}{c}0.997 \\
6\end{array}$ & 89.90 & $\begin{array}{c}0.996 \\
6\end{array}$ \\
\hline$L s C Y P^{a}$ & $\begin{array}{l}\text { peptidyl-prolyl cis-trans isomerase } \\
\text { 1-like }\end{array}$ & LOC101206458 & BG_GLEAN_10006142 & CACACCGGCCCTGGTATTTT/CATCCATGCC TTCAACGACT & 139 & $\begin{array}{c}83 . \\
5\end{array}$ & 107.09 & $\begin{array}{r}0.991 \\
4\end{array}$ & 95.00 & $\begin{array}{r}0.994 \\
1\end{array}$ \\
\hline LsL23A & $60 \mathrm{~S}$ ribosomal protein L23a & LOC101220073 & BG_GLEAN_10025920 & AAGGATGCCGTGAAGAAGATGT/GCATCGTAGTCAGGAGTCAACC & 110 & $\begin{array}{c}82 . \\
2\end{array}$ & 93.99 & $\begin{array}{r}0.999 \\
7\end{array}$ & 98.49 & $\begin{array}{r}0.995 \\
8\end{array}$ \\
\hline LsIPT & $\begin{array}{l}\text { adenylate isopentenyltransferase } \\
\text { (cytokinin synthase) }\end{array}$ & LOC101204427 & BG_GLEAN_10016404 & GCACTCCAATGGCTCGTTTA/GGTCGATGGTGGATTTGTCG & 89 & $\begin{array}{c}83 . \\
0\end{array}$ & 107.39 & $\begin{array}{c}0.997 \\
2\end{array}$ & 93.23 & $\begin{array}{c}0.995 \\
1\end{array}$ \\
\hline$L s D d R P$ & $\begin{array}{l}\text { DNA-directed RNA polymerase } \\
\text { subunit }\end{array}$ & LOC101215872 & BG_GLEAN_10015299 & AAACTCCCTTTCAGCCTCGA/AGATGTGGCCCTGTTGAGAA & 174 & $\begin{array}{c}81 . \\
6\end{array}$ & 95.45 & $\begin{array}{c}0.998 \\
4\end{array}$ & 96.07 & $\begin{array}{c}0.997 \\
1\end{array}$ \\
\hline
\end{tabular}

Bottle gourd gene ID in the NCBI Database (https://www.ncbi.nlm.nih.gov/) and GourdBase (http://www.gourdbase.cn/) were listed. The two genes labeled as aqua green were selected from RNA-seq data which met the criteria (RPKM $>40$, RPKMmax $/ \min <2.0$ ) to be candidate RGs for both leaves and fruits. The fourteen genes labeled as light gray were selected from the traditional RG used in Cucurbitaceae crops. ${ }^{a}$ indicated the candidate reference genes selected for following analysis in bottle gourd leaves, and ${ }^{b}$ indicated the candidate reference genes selected for following analysis in bottle gourd fruits. 


\section{Table 2 (on next page)}

Primer sequences and PCR amplification characteristics for candidate RGs selected from bottle gourd RNA-seq database. 
1 Table 2 Primer sequences and PCR amplification characteristics for candidate reference genes selected from bottle gourd 2 RNA-seq database.

\begin{tabular}{|c|c|c|c|c|c|c|c|c|}
\hline $\begin{array}{l}\text { Gene } \\
\text { name }\end{array}$ & Description & $\begin{array}{c}\text { NCBI } \\
\text { Homolog locus }\end{array}$ & $\begin{array}{c}\text { Gourdbase } \\
\text { Homolog locus }\end{array}$ & $\begin{array}{l}\text { Forward primer Sequence/Reserve primer } \\
\text { sequenc }\left(5^{\prime}-3^{\prime}\right)\end{array}$ & $\begin{array}{l}\text { Product } \\
\text { size (bp) }\end{array}$ & $\begin{array}{l}\text { Tm } \\
\left({ }^{\circ} \mathrm{C}\right)\end{array}$ & E $(\%)$ & $\mathbf{R}^{2}$ \\
\hline \multicolumn{9}{|c|}{ Primers and amplicon characteristics for candidate internal control genes from bottle gourd leaves } \\
\hline LsARL & ADP-ribosylation factor-like & LOC103504673 & BG_GLEAN_10014274 & GCTGGTCGAAAGTTGACTCC/GTCAAGGCCAAAGAGTAGGCA & 109 & 82.7 & 106.80 & 0.9988 \\
\hline LSTPT & triose phosphate/phosphate translocator & LOC103483570 & BG_GLEAN_10024475 & ACCACCTACGATTGGCAGAAG/GTCTGGGAAAAGTGGCGGTAT & 140 & 81.7 & 102.65 & 0.9838 \\
\hline LSSRK2I & serine/threonine-protein kinase SRK2I & LOC101206398 & BG_GLEAN_10004502 & TTGACCACTACCCATCTTGCA/GCGAGCCTCATCCTCACTAA & 102 & 81.7 & 90.54 & 0.9945 \\
\hline LSCNX & calnexin homolog & LOC101207554 & BG_GLEAN_10001815 & TCGCTCTCTCATCCCAATCC/GTGCGCATTCTCATTGATGGG & 139 & 86.5 & 101.26 & 0.9940 \\
\hline$L s P D I$ & protein disulfide-isomerase-like & LOC103504071 & BG_GLEAN_10010057 & AGGCCCACTTTGCTTCTTCAA/GAGCAGTCATGACCCTCCAAT & 199 & 82.2 & 98.27 & 0.9967 \\
\hline LsSK & shaggy-related protein kinase & LOC103490499 & BG_GLEAN_10005566 & CTTGCTTCACGTCTGCTTCAA/GTTGTTAGGGAGGCGGACATT & 114 & 81.7 & 95.34 & 0.9935 \\
\hline$L s U B C$ & ubiquitin $\mathrm{C}$ & LOC111803940 & BG_GLEAN_10016554 & CACTTGGTGCTTCGTCTCAG/TCGATCGTGTCAGAGCTCTC & 98 & 81.7 & 98.75 & 0.9957 \\
\hline LSGAD & glutamate decarboxylase & LOC103501361 & BG_GLEAN_10014712 & TGTCATAGGGCTTGCCTTCAG/CATTGGGTGATGCTGAGACG & 129 & 84.6 & 99.77 & 0.9966 \\
\hline$L s R N C$ & ribonuclease III domain-containing protein $\mathrm{RNC1}$ & LOC111803262 & BG_GLEAN_10017046 & TACATCTTCAAGTTGCCTGCGT/CCAGAAGTGTACCGGGTTCT & 93 & 81.0 & 94.31 & 0.9976 \\
\hline \multicolumn{9}{|c|}{ Primers and amplicon characteristics for candidate internal control genes from bottle gourd fruits } \\
\hline Ls ARIA & arm repeat protein interacting $\mathrm{ABF} 2$ & LOC103483725 & BG_GLEAN_10016382 & CTCCCCAATGCAAAAGCTGAC/GAGGTGCTGTTCGACCCTTAA & 82 & 83.9 & 102.99 & 0.9869 \\
\hline$L s P 4 H$ & prolyl 4-hydroxylase & LOC103485167 & BG_GLEAN_10016694 & AGAGAGAGAGAGGCCTTGGA/CCTGTGTTTC GCCATGGAAAC & 126 & 82.0 & 91.04 & 0.9951 \\
\hline LsXRNI & 3'-5' exoribonuclease 1 & LOC101214656 & BG_GLEAN_10010883 & ACCTTCCAGATCACACCAGG/AGGCCTCACAGTTCCTCTTC & 129 & 81.2 & 111.01 & 0.9928 \\
\hline LSPARP & inactive poly [ADP-ribose] polymerase & LOC103503572 & BG_GLEAN_10013282 & TTGGAGTCTTCAGGGAGCTG/TCCTCTTGAACGTGGGGTAC & 143 & 81.3 & 93.05 & 0.9970 \\
\hline LsYpgQ & uncharacterized protein $\mathrm{YpgQ}$ & LOC103500350 & BG_GLEAN_10019270 & ATGGCGAAAAGAGAAACGGTG/GAAGGATCATGTGACGCGTC & 83 & 84.1 & 115.47 & 0.9986 \\
\hline LsEIF5 & eukaryotic translation initiation factor 5 -like & LOC103488416 & BG_GLEAN_10010896 & GCAGCCAATAGTCTCAGCAC/GTAGTTCAAAGTGGAGGGCGT & 142 & 81.6 & 94.77 & 0.9939 \\
\hline LSVAMP & vesicle-associated membrane protein 72 & LOC103502784 & BG_GLEAN_10013195 & AACCTTCGATCTCAGGCACAA/CGCCGCAGACAGACAAAATGA & 145 & 84.4 & 104.32 & 0.9947 \\
\hline$L s P L$ & Phospholipase-like & LOC101210853 & BG_GLEAN_10006169 & CGAATGGGACTCTGCTTTGG/TATTCCGACGAAATCCATCCG & 131 & 83.1 & 96.42 & 0.9925 \\
\hline LSISCA & iron-sulfur assembly protein IscA-like 1 & LOC103489389 & BG_GLEAN_10023226 & ATGGCAGCTTCTTCGTCTTCC/TGGCGCTGTTGAAGAAGTTGT & 127 & 82.7 & 97.43 & 0.9929 \\
\hline LsclpC & ATP-dependent Clp protease ATP-binding subunit $\mathrm{ClpC}$ & LOC101207209 & BG_GLEAN_10001965 & TGTGGATGTTGATTCTGATGGA/ACAGGTTACACAGGAATAGCATC & 90 & 79.2 & 94.59 & 0.9971 \\
\hline LsCRCK3 & calmodulin-binding receptor-like cytoplasmic kinase 3 & LOC103487406 & BG_GLEAN_10008798 & ACCGACTGTCCCTTTCACTTG/GTGGCGGATTTTGGATTTGCAA & 83 & 85.0 & 93.72 & 0.9986 \\
\hline
\end{tabular}

4 Bottle gourd gene ID in the NCBI Database (https://www.ncbi.nlm.nih.gov/) and GourdBase (http://www.gourdbase.cn/) were listed. 